\title{
Old, new and emerging functions of caspases
}

\author{
S Shalini ${ }^{1}$, L Dorstyn ${ }^{1}$, S Dawar ${ }^{1}$ and S Kumar ${ }^{*}, 1$
}

Caspases are proteases with a well-defined role in apoptosis. However, increasing evidence indicates multiple functions of caspases outside apoptosis. Caspase- 1 and caspase-11 have roles in inflammation and mediating inflammatory cell death by pyroptosis. Similarly, caspase-8 has dual role in cell death, mediating both receptor-mediated apoptosis and in its absence, necroptosis. Caspase-8 also functions in maintenance and homeostasis of the adult T-cell population. Caspase-3 has important roles in tissue differentiation, regeneration and neural development in ways that are distinct and do not involve any apoptotic activity. Several other caspases have demonstrated anti-tumor roles. Notable among them are caspase-2, -8 and -14 . However, increased caspase-2 and -8 expression in certain types of tumor has also been linked to promoting tumorigenesis. Increased levels of caspase-3 in tumor cells causes apoptosis and secretion of paracrine factors that promotes compensatory proliferation in surrounding normal tissues, tumor cell repopulation and presents a barrier for effective therapeutic strategies. Besides this caspase-2 has emerged as a unique caspase with potential roles in maintaining genomic stability, metabolism, autophagy and aging. The present review focuses on some of these less studied and emerging functions of mammalian caspases.

Cell Death and Differentiation (2015) 22, 526-539; doi:10.1038/cdd.2014.216; published online 19 December 2014

Facts

- Caspases are involved in cell death mediated by apoptosis, pyroptosis, necroptosis and autophagy.

- Caspase function is not limited to cell death.

- Non-apoptotic roles of caspases include proliferation, tumor suppression, differentiation, neural development and axon guidance and aging.

\section{Open Questions}

- What are the mechanisms by which a caspase can mediate both cell death and non-cell death functions?

- In vivo validation of some of the proposed functions of caspases remains to be addressed.

- Are there other as yet undiscovered physiological roles for caspases?

Cell death is a fundamental process that maintains tissue homeostasis, removes unwanted or damaged cells and ensures recycling of cellular constituents promoting further growth and differentiation. Based on the morphology of dying cells two distinct modes of cell death commonly studied include apoptosis and necrosis, however, other types of cell death types have been recently described. ${ }^{1-3}$

Caspases (cysteine-aspartic proteases) are proteolytic enzymes largely known for their role in controlling cell death and inflammation. The function of caspases in cell death was identified more than two decades ago with the discovery of ced-3 as an executioner of cell death during development of the nematode Caenorhabditis elegans. ${ }^{4}$ The first mammalian ced-3 homologs included interleukin-1-beta-converting enzyme (ICE), later renamed caspase- $1,{ }^{5}$ and Nedd2, renamed caspase-2. ${ }^{6,7}$ Owing to inconsistencies in naming caspases, 18 mammalian caspases are known. ${ }^{8}$ However, newly identified caspases-15, -17 and -18 are absent in placental mammals with the exception of caspase-16 (Figure 1). ${ }^{8}$ It is also important to note that caspase-5 is not present in mice and caspase-11 and -13 are the murine and bovine orthologues of caspase- 4 , respectively. ${ }^{8,9}$ Caspase-12 exists in both truncated and full-length alleles in humans and as a full-length caspase in rodents. ${ }^{10}$ Caspase-14 is expressed in the epidermis and has a primary role in cornification and protection of underlying layers of skin. ${ }^{11}$

Based on their function, mammalian caspase-2, -3, -7, -8, -9 and -10 are apoptotic caspases, where as caspase-1, $-4,-5$, -11 and -12 are involved in inflammation. The apoptotic caspases are subdivided into the initiators and the effectors based on the presence or absence of specific-protein

\footnotetext{
${ }^{1}$ Centre for Cancer Biology, University of South Australia, Adelaide, SA 5001, Australia

${ }^{*}$ Corresponding author: S Kumar, Centre for Cancer Biology, University of South Australia, Frome Road, Adelaide, SA 5001, Australia. Tel: +61 8 8222 3738 ; Fax: +61 88222 3162; E-mail: sharad.kumar@unisa.edu.au

Abbreviations: ROS, reactive oxygen species; Apaf-1, apoptotic protease-activating factor 1; CARD, caspase-recruitment domains; CFLIP, cellular FLICE (FADD-like IL-1 $\beta$-converting enzyme)-inhibitory protein; CIAP, cellular inhibitor of apoptosis protein; DED, death effector domains; DISC, death-inducing signaling complex; HCC, Hepatocellular carcinoma; NEMO, NF-kB essential modulator; FADD, FAS-associated death domain protein; MLKL, Mixed lineage kinase domain-like protein; MOMP, mitochondrial outer membrane permeabilization; PAMPs, pathogen-associated molecular patterns; PIDD, p53-inducible protein with a death domain; RAIDD, RIP-associated Ich-1/Ced-3 homologous protein with a death domain; RIP1, Receptor-interacting protein 1; RIP3, Receptor-interacting serine-threonine kinase 3; TLR3, Toll-like receptor 3; LTP, Long-term potentiation; TNFR, tumor necrosis factor receptor; TRADD, TNFR-associated death domain protein; TRAF, TNF receptor-associated factors; TRAIL, TNF-related apoptosis-inducing ligand

Received 23.10.14; revised 13.11.14; accepted 19.11.14; Edited by G Melino; published online 19.12.14
} 


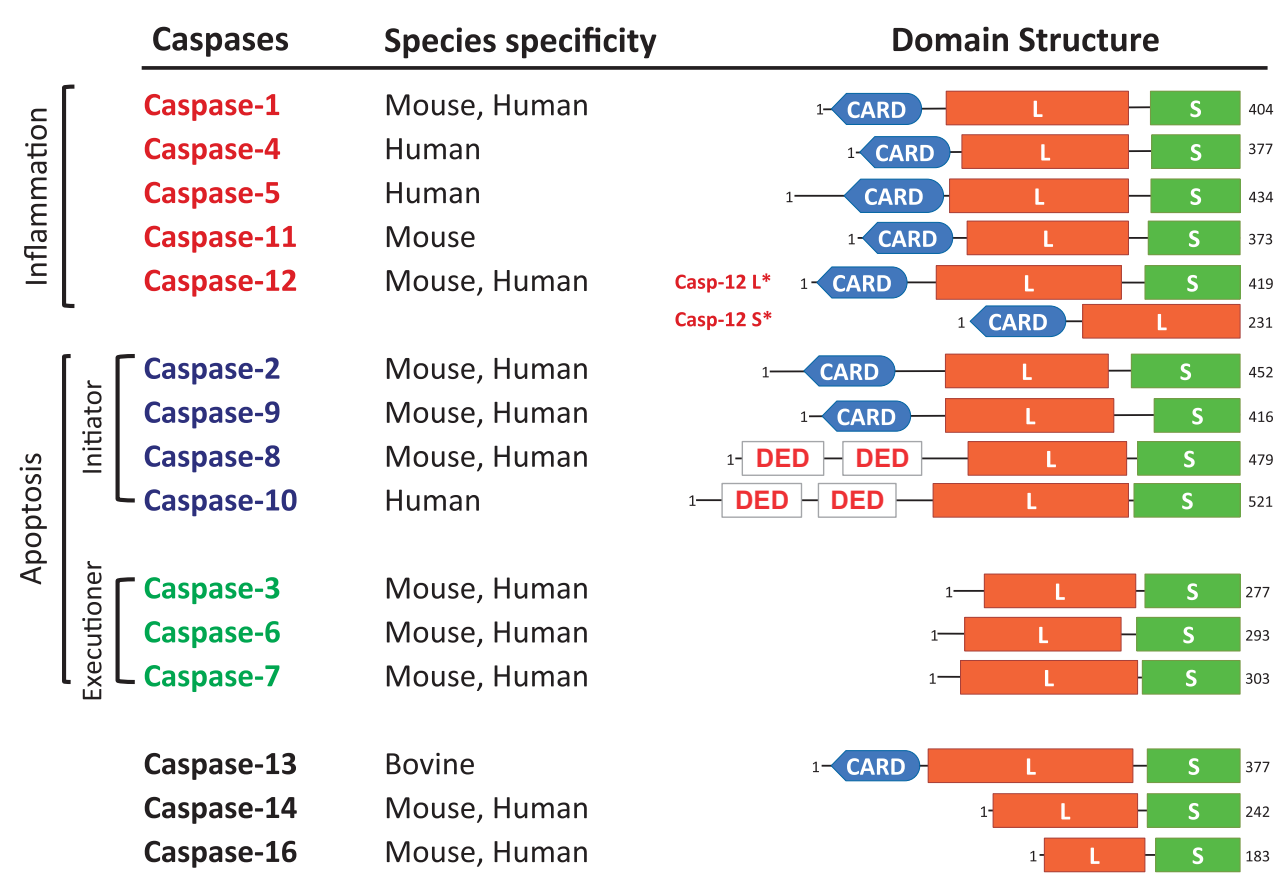

Figure 1 Domain structure and functional classification of placental mammalian caspases. Caspase-1, $-4,-5,-11$ and -12 are inflammatory caspases. Apoptotic caspase-2, $-8,-9$ and -10 are initiators, while caspase- $3,-6$ and -7 are key executioner caspases. CARD, caspase recruitment domain; DED, death effector domain; L, large subunit; S, small subunit; $\mathrm{S}^{*}$, short form; $L^{*}$, long form

interaction domains toward the $\mathrm{N}$-terminus (Figure 1). Initiator caspases comprise death effector domains (DED; caspase-8 and -10) or caspase-recruitment domains (CARD; caspase-2, $-9,-1$ and -11), which mediate their dimerization and/or recruitment into larger complexes to facilitate their activation. ${ }^{12}$

Initiator caspase activation during apoptosis is mediated by two main pathways; the mitochondrial or Bcl-2-regulated (intrinsic) pathway and the death receptor (extrinsic) pathway (Figure 2). The intrinsic pathway is activated in response to cellular stress (e.g., cytotoxic drugs, DNA damage) and is regulated by the $\mathrm{Bcl}-2$ family of proteins. This pathway involves activation of the pro-apoptotic effectors BAX and BAK, which induce mitochondrial outer membrane permeabilization (MOMP) and cytochrome $c$ release. Apaf-1 (apoptotic protease-activating factor 1) associates with cytochrome $c$ into a large multimeric complex called the apoptosome to activate caspase-9. ${ }^{13}$ Death receptor-mediated apoptosis is initiated following ligand-binding and activation of the deathdomain-containing tumor necrosis receptor superfamily (e.g., TNFR, Fas, TRAIL). ${ }^{14}$ This mediates recruitment and activation of caspase-8 or -10 , through the death-inducing signaling complex (DISC) comprising FAS-associated death domain protein (FADD) and/or TNFR-associated death domain protein (TRADD) and other components. Caspase-8 also cleaves BID to a truncated form (tBID), which engages the mitochondrial pathway to amplify the apoptotic response. ${ }^{15}$ Once initiator caspases are activated through the extrinsic or intrinsic apoptosis pathways, they mediate activation of effector caspases-3, -6 and -7 .

Caspase-2 is unique, in that it can be activated both upstream of MOMP and/or downstream of MOMP following various apoptotic stimuli. The activation of caspase-2 is primarily via CARD-mediated homo-dimerization and auto-proteolysis. ${ }^{16,17}$ Caspase-2 is also recruited to a large multiprotein complex called the PIDDosome, comprising proteins RAIDD and PIDD, ${ }^{18}$ and can also interact with RAIDD independent of PIDD. However, RAIDD and PIDD are not required for caspase-2 activation in vivo, which can occur normally in RAIDD- and PIDD-deficient mice. ${ }^{19}$ Caspase-2 has been implicated in cell death induced by metabolic imbalance in oocytes, in mitotic catastrophe and in functions outside apoptosis. ${ }^{20}$

In recent years, it has become evident that the role of many caspases is not limited to apoptosis and that they function in other modes of cell death (necrosis, autophagy and pyroptosis). Furthermore, several other non-cell death functions have emerged. We begin by first addressing the role of caspases in cell death pathways other than apoptosis.

\section{Caspases in Non-Apoptotic Cell Death}

Necroptosis. Cell death by necroptosis is typically induced when caspase activity is blocked, and is morphologically characterized by an increase in cell volume, swelling of organelles and rupture of the plasma membrane. ${ }^{21}$ Necroptosis can be initiated following stimulation of the Toll-like receptor TLR3, genotoxic stress or 'pathogen-associated molecular patterns (PAMPs). ${ }^{22}$ However, the best-studied model is TNF-induced necroptosis. ${ }^{23}$ Upon stimulation by TNF, TNFR1 recruits TRADD, RIP1, TRAFs and IAPs into a complex called TRADD-dependent complex I. Formation of this complex ensures activation of the canonical $\mathrm{NF}_{\kappa} \mathrm{B}$ signaling pathway. Subsequently removal of polyubiquitin chains from RIP1, allows RIP1 to dissociate from the plasma membrane and interact with TRADD, FADD, procaspase-8 and $C F L I P_{L}$ as a TRADD-dependent complex lla (also called 
DISC; Figure 2). Caspase-8 then cleaves RIP1 and RIP3 and initiates apoptosis. Alternatively, by chemical or viral inhibition of caspase-8, or in the absence of clAPs, another multiprotein complex called the ripoptosome is formed, which

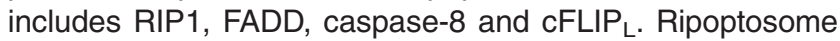
formation is dependent on RIP1, which can then mediate either apoptosis or necroptosis depending on the presence and levels of cFLIP proteins and caspase-8 activity. ${ }^{23}$ When caspase activity is inhibited, RIP1 and RIP3 are stabilized, undergo auto and trans-phosphorylation and recruit MLKL into a complex called the necrosome (complex $\mathrm{Ilb}$ ), that initiates necroptosis. Alternatively, caspase- 8 activation leads to cleavage of RIP1 and RIP3, this prevents necroptosis but apoptosis can still occur (Figure 2). ${ }^{23,24}$ RIP1 is thus a master regulator of cell fate that acts to regulate caspase-8-mediated apoptosis or promote RIPK3-MLKL-dependent necroptosis signaling pathway when apoptosis is blocked. ${ }^{25,26}$ Blocking the activity of RIP1 completely inhibits necroptosis. ${ }^{27}$ Interestingly, RIP1 can also inhibit necroptosis to mediate pro-survival and inflammatory signaling via TLR complexes and $\mathrm{NF}_{K} \mathrm{~B}$ signaling. ${ }^{25,26}$ Furthermore, recent studies have demonstrated that RIP1-caspase-8 signaling functions as the critical cell fate decision point that drives either cell survival or cell death. RIP1 functions to protect cells from excessive caspase-8-mediated apoptosis and TNF-driven inflammation to maintain cell homeostasis in barrier tissues such as the gut epithelium and skin. ${ }^{28,29}$

Pyroptosis. Cell death by pyroptosis was first observed in macrophages following infection with Shigella flexneri or Salmonella typhimurium. ${ }^{30,31}$ This cell death was later characterized as a novel programmed cell death process, distinct from apoptosis. ${ }^{32,33}$ Pyroptosis is a caspase-1- and -11-dependent cell death process and is considered an immune response to dispose of microbe-laden macrophages and clear intracellular pathogens in response to acute bacterial or viral infection or exposure to bacterial toxins. The process involves activation of these inflammatory

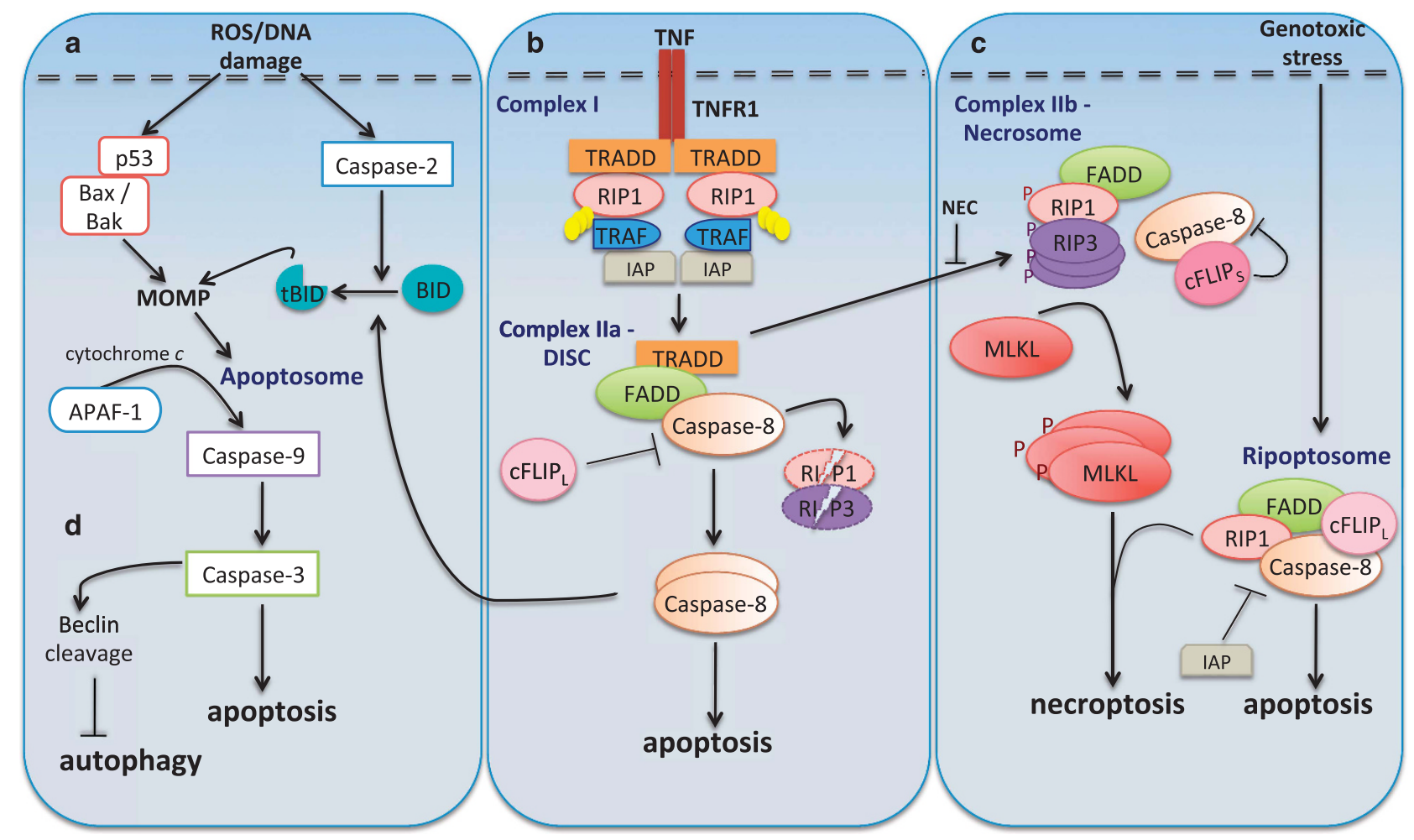

Figure 2 Caspases in cell death pathways. Caspases have been implicated in apoptosis, necroptosis and autophagy. Apoptosis can proceed in two ways: intrinsic or extrinsic. (a) Intrinsic apoptosis is initiated by a death-inducing stimulus, which causes activation of p53 and pro-apoptotic Bcl-2 proteins such as Bax and Bak. This leads to MOMP and activation of a death-inducing platform called the apoptosome. Following this caspase-9 is cleaved and activates other effector caspases such as caspase-3. Alternatively, caspase-2 gets activated following DNA damage and causes MOMP by cleaving Bid. (b) Extrinsic or receptor-mediated apoptosis involves complex formation by death-domain-containing proteins (called DISC), activation of caspase-8, which initiates apoptosis by directly activating effector caspases. Caspase-8 also cleaves Bid and this causes cytochrome $c$ release, further amplifying apoptosis via the mitochondrial/intrinsic pathway. Depending on ligands (TNF and Fas) different complexes are formed. TNF stimulates TNFR1 that recruits TRADD, RIP1, TRAFs and IAPs into a complex called TRADD-dependent complex I. Subsequent removal of polyubiquitin on RIP1, dissociates this complex and allows it to interact with TRADD, procaspase-8, FADD and cFLIP as complex Ila/DISC. This results in caspase-8 activation, leading to apoptosis. (c) In certain conditions when caspase activity is blocked, RIP1, FADD and the FLIPL-caspase-8 heterodimer, form a large multiprotein complex called the 'ripoptosome' following genotoxic stress. If caspase activity is lost, RIP1 and RIP3 are stabilized and associate in microfilament-like complexes called necrosomes (complex Ilb). Recruitment of MLKL complex at the plasma membrane occurs, leading to pore formation and necroptotic cell death. Alternatively, RIPK1 and RIPK3 are inactivated by active caspase-8 and apoptosis occurs. Necroptosis can also occur following stimulation of TNF receptor or activation of Toll-like receptors (TLRs). (d) Some caspases such as caspase-3, mediate cleavage of crucial autophagic proteins and thus indirectly control autophagy. FADD, FAS-associated death domain; TNFR1, TNF receptor 1; TRADD, TNF receptor-associated death domain; cIAP1, cellular inhibitor of apoptosis protein 1; RIP1, receptor-interacting protein 1; MLKL, mixed lineage kinase domain-like; cFLIP, cellular FLICE-like inhibitory proteins; MOMP, mitochondrial outer membrane permeabilization 
caspases, resulting in plasma membrane pore formation allowing water influx, cell swelling and osmotic lysis, followed by release of proinflammatory intracellular contents. ${ }^{32,34}$ This demarcates it clearly from apoptosis where no loss of membrane integrity is observed. At the same time cytokines are secreted either through the newly formed plasma membrane pores or through microvesicles- or lysosomemediated exocytosis. ${ }^{35}$ The pyroptosis of macrophages also releases the bacteria that can be taken up by neutrophils as a secondary mechanism of phagocytic clearance and destroyed through the NADPH oxidase system. ${ }^{36}$ Chromosomal DNA cleavage and nuclear condensation occurs in pyroptosis but in the absence of oligonucleosomal DNA fragmentation or cleavage of typical caspase substrates such as PARP and ICAD that are characteristic of apoptosis. ${ }^{34,37}$

Autophagy. Cross talk between autophagy and apoptosis is well established. ${ }^{38}$ Initiation of apoptosis by inhibiting autophagy is beneficial for execution of cell death since autophagy is often considered a pro-survival mechanism. Several human ATG proteins can be cleaved by calpain or caspases. hATG3 has been shown to be cleaved by caspase$3,-6$ and -8 . $^{39}$ Beclin-1/ATG-6 is a caspase-3 target $^{40}$ and cleaved beclin-1 reduced autophagy and promoted apoptosis in HeLa cells. ${ }^{41}$ Caspase- 6 and -8 also cleave p62 that serves to inhibit autophagy. ${ }^{42}$ Other studies have shown that hATG3 is a direct target of caspase-8, and cleavage of ATG3 blocked autophagy. ${ }^{43}$ Recently, the Drosophila effectorcaspase Dcp-1 was found to localize to mitochondria following starvation-induced stress and functions to positively regulate autophagy. ${ }^{44}$

A recent study suggests caspase-2 as a repressor of autophagy. ${ }^{45}$ Cells/tissues lacking caspase-2 show upregulation of autophagy, which provides them with a survival advantage. Importantly, caspase-2-induced autophagy in a mTOR-AMPK dependent pathway with accompanying MAPK1/3 activation and MAPK14 repression. ${ }^{45}$ Atg4 and AMBRA1 are examples of other autophagic proteins that are caspase targets. ${ }^{46,47}$

Mitotic catastrophe. Mitotic catastrophe is a cell death mechanism that occurs during mitosis in cells that have accumulated DNA damage due to dysregulated checkpoint mechanisms. $^{3}$ Such cells would normally arrest cell-cycle progression into mitosis and hence suppress catastrophic events until DNA repair has been achieved. ${ }^{48}$ Although cellcycle kinase such as cyclin B1-dependent kinase Cdk1, pololike kinases and aurora kinases and other cell-cycle checkpoint proteins, are key players in regulating this process, cell death occurs via caspase activation, including caspase-2. ${ }^{48}$

\section{Caspases in Inflammation and Immunity}

The first indication of a role for caspases in inflammation came from the identification of caspase- 1 function in the processing and maturation of interleukin (IL) cytokine family members IL- $1 \beta$ and IL-18, critical mediators of inflammation. ${ }^{49,50}$ Mice deficient for caspase-1 exhibit defective maturation of proIL-1 $\beta$ and pro-IL-18, are resistant to LPS-induced endotoxic shock $^{50-52}$ and are protected from experimental mucosal inflammation. 53

Additional studies in Drosophila unexpectedly identified the ortholog of caspase-8, Dredd, in a genetic screen as a regulator of the innate immune response. ${ }^{54}$ In particular, Dredd interacts with a Drosophila NF-kB protein, Relish, in the immune deficiency (IMD) pathway, leading to Relish cleavage and activation, following exposure to Gram-negative bacteria. ${ }^{54,55}$ Loss-of-function dredd mutants exhibit high susceptibility to Gram-negative bacteria, and defective production of antibacterial peptides, such as drosomycin ${ }^{54}$ further substantiating an important role for this Drosophila caspase in immune regulation.

In mammals, there are now several caspases, which have been identified as important mediators of the innate immune response, termed the 'inflammatory caspases' and include human caspase-1, -4, -5, -12 and mouse caspase-1, -11 and $-12 .^{34,56}$ Caspase- 1 is the prototypical member of the inflammatory caspase family, while; the functions of caspase-4 and -5 are not well defined (caspase- 5 is absent in mice and mouse caspase-11 is a paralogue of human caspase-4). Caspase-11 has been suggested to be an upstream activator of caspase- 1 but unlike caspase-1, caspase-11 expression is induced by LPS at the transcriptional level. ${ }^{57}$ Indeed, caspase$4,-5$, and -11 act as cytoplasmic LPS receptors and have the ability to directly bind LPS via CARD domain, causing oligomerization and cell death. This represents a novel mechanism for inflammasome activation that is distinct from LPS sensing and activation of caspase-1. ${ }^{58}$

In contrast to the roles of other inflammatory cytokines, caspase-12 can abrogate the inflammatory response in mice by inhibiting caspase-1, in a protease-independent function. ${ }^{59}$ As a result, mice deficient for caspase-12 show increased bacterial clearance and resistance to sepsis. ${ }^{60}$ Interestingly, full-length human caspase-12 protein is expressed only in $\sim 20 \%$ of sub-Saharan African descendants, who as a consequence exhibit weakened inflammatory and innate immune responses and increased susceptibility to sepsis. ${ }^{61}$

The activation of inflammatory caspases is mediated through their recruitment to large multiprotein complexes known as 'inflammasomes'. ${ }^{62,63}$ In response to specific internal or external cellular insults (viral or bacterial infection, toxin exposure, environmental irritants and metabolites), the specific activation of different pattern-recognition receptors (PRRs), leads to formation of distinct inflammasome complexes. There are three main classes of PRRs, activated in response to specific pathogenic stimuli, including (i) TLRs that can detect PAMPs derived from bacteria, viruses and fungi; (ii) retinoic acid-inducible gene (RIG)-l-like receptors (RLRs), which detect virus infection; and (iii) the family of bacterialsensing NOD-like receptor proteins (NLRs) or nucleotidebinding domain, leucine-rich repeat-containing proteins. ${ }^{64}$

Caspase- 1 is activated by recruitment to multiple NLRdriven inflammasomes depending on the specific stimuli (Figure 3). There are currently four major, well-characterized inflammasomes: (i) NLRP1 inflammasome activated in response to the anthrax lethal toxin $(L T)^{62}$; (ii) NLRP3/ NALP3/cryopyrin inflammasome is activated by a wide range of PAMPs as well as whole pathogens, including fungi ${ }^{56,62}$; (iii) the NLRC4/IPAF inflammasome, which senses bacterial 


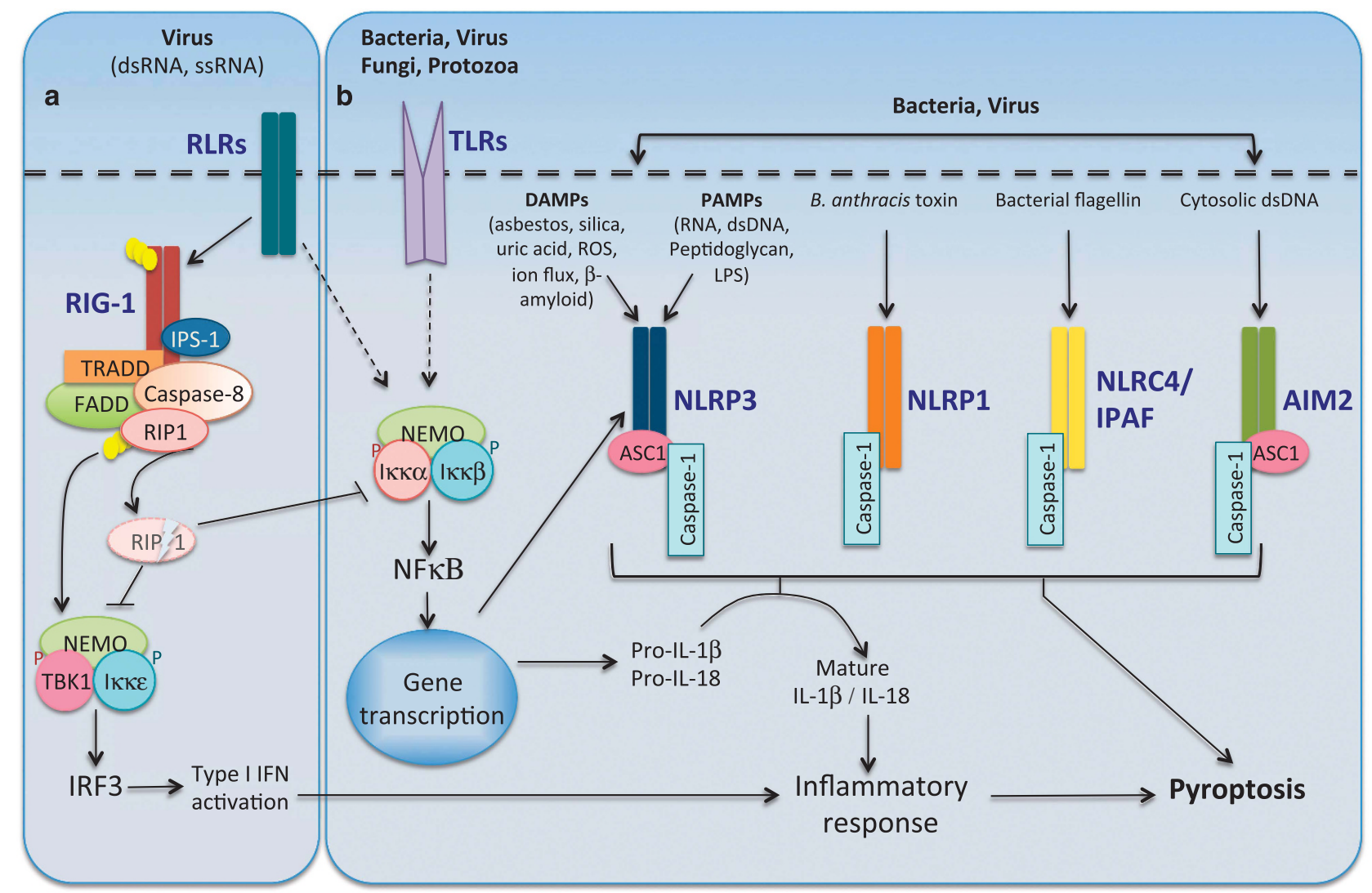

Figure 3 Caspase-mediated inflammatory responses. (a) Caspase-8 functions to restrict RIG-1 signaling. Activation of the retinoic-acid-like receptors (RLRs) are critical for anti-viral immunity. Following viral infection the caspase-8 DISC complex comprising FADD, TRADD and ubiquitin-conjugated RIP1 (Ub-RIP1) are recruited to the RIG-1 complex. Although Ub-RIP1 can enhance the phosphorylation of IRF3, it is also cleaved by activated caspase-8. Cleaved RIP1 inhibits IRF3 and NF $k$ B thereby reducing the type I interferon (IFN) and IL-1 $\beta$-/IL-18-mediated inflammatory responses. (b) Inflammasome complex formation is triggered by specific pathogen-associated molecular patterns (PAMPs) or by damage-associated molecular patterns (DAMPs). Activation of Toll-like receptors (TLRs) following pathogen exposure induces NF $\kappa$ B-mediated transcription of IL-1 $\beta$, IL-18 and also NLRP3, and this is an important step in inflammasome priming and activation. Caspase-1 activation is mediated by its recruitment to different inflammasome complexes (NLRP3, NLRP1, NLRC4 and AIM2) in an ASC-dependent or independent manner. Activated caspase-1 mediates the cleavage and maturation of pro-inflammatory cytokines $\mathrm{IL}-1 \beta$ and IL-18. Following acute infection and an acute inflammatory response, caspase-1 induces cell death by pyroptosis

flagellin and various secreted proteins from Gram-negative bacteria ${ }^{65}$; and (iv) AIM2 inflammasome, an atypical NLR, activates caspase-1 in response to cytosolic dsDNA. ${ }^{66}$ NLRP1 and NLRC4 can bind and activate caspase-1 directly via a CARD-CARD-mediated interaction. In contrast, NALP3 and AIM2 do not comprise a CARD domain and require, the CARD/pyrin-containing inflammasome adapter, apoptosisassociated speck-like protein (ASC), to recruit caspase-1 to these inflammasomes. The NLRP1 inflammasome can also recruit caspase- 5 via the CARD of the inflammasome adapter protein, CARDINAL, ${ }^{62,67}$ but the requirement of CARDINAL in caspase- 5 activation by NALP 1 is unclear.

The first step toward an inflammasome-mediated immune response requires a process known as inflammasome priming, where stimulation of TLR or RIG leads to transcriptional activation of NALP3 and inflammatory cytokines (proIL- $1 \beta$, IFN). Activation of the NALP3 inflammasome only occurs following detection of PAMPs as a second stimulus, and contrary to previous studies, ${ }^{68}$ does not involve mitochondrial-mediated apoptosis signaling. ${ }^{69}$ Recruitment and activation of caspase- 1 by the inflammasome complex is a critical second step in the cleavage and activation of pro-inflammatory cytokines, IL-1 $\beta$ and IL-18, facilitating their secretion and promotion of innate immune responses. Although caspase- 1 activation is required to activate inflammatory cytokines, it induces pyroptosis-mediated proinflammatory cell death following acute infection (Figure 3).

A novel role for caspase- 8 in the regulation of inflammasome activation and maturation of pro-inflammatory cytokines has recently been revealed. Cleavage of pro-IL- $1 \beta$ can be mediated by both caspase-1 and caspase- $8 .{ }^{70,71}$ Interestingly, deletion of caspase-8 in RIP3 knockout bone-marrow-derived macrophages (BMDMs) results in significant reduction of proIL- $1 \beta$ and TNF transcription levels, and reduced NALP3 activation following TLR stimulation. Importantly, this role for caspase-8 in the regulation of inflammasome priming is independent of apoptosis ${ }^{69}$ and highlights an unexpected role for this caspase in immune homeostasis. Previous studies have also reported an inflammasome-independent role for caspase-8 in inhibiting extensive inflammation in vivo. ${ }^{72,73}$ Conditional deletion of caspase-8 in hepatocytes, augments Listeria infection in liver and chronic inflammation following hepatectomy. ${ }^{73}$ Caspase- 8 deficiency also protects against inflammation-related hepatocarcinogenesis, while inducing 
necrosis-mediated liver injury. ${ }^{74}$ In addition, conditional deletion of caspase-8 in epidermal keratinocytes, is associated with chronic skin inflammatory disease associated with constitutive IRF3 signaling. ${ }^{72}$ Interestingly, this role for caspase-8 in suppressing inflammation is independent of signaling mediated through TNF, IL-1 $\beta$ or TLR receptors and independent of NFK $\beta$ signaling. Instead, caspase- 8 regulates the activation of the IKK-related, TANK-binding kinase 1 (TBK1) and IRF3 to downregulate the inflammatory response. ${ }^{72}$ Later reports demonstrated that caspase-8 suppresses inflammation following viral RNA-induced RIG-1 signaling $^{75}$ by interaction with the RIG-I signaling complex, RIP1 cleavage and inhibition of IRF3-mediated activation of interferons (Figure 3). ${ }^{75}$

Mutations in NALP3 and defective inflammasomes are associated with innate-immune-mediated diseases, and aberrant IL-1 processing has been reported in numerous autoinflammatory diseases including gout, diabetes and juvenileonset arthritis. ${ }^{76}$ Mutations in caspase-8 (and caspase-10) are also associated with autoimmune lymphoproliferative syndrome (ALPS). ${ }^{9}$ Detailed understanding of the regulation of caspase activation during inflammation and secretion of pro-inflammatory cytokines will potentially provide new avenues for treatment of inflammatory and infectious diseases.

\section{Caspases in Cell-Fate Determination and Differentiation}

Early studies in Drosophila were instrumental in delineating a role for caspases in cell fate and differentiation. Loss-of-function mutation of the Drosophila Apaf-1 ortholog, dark, reduces activation of the initiator caspase, Dronc and abolishes developmental apoptosis. ${ }^{77,78}$ Interestingly, dark-mutant flies expressing a dominant-negative form of Dronc, have defects in development with extra sensory organ precursor (SOP) cells. ${ }^{79}$ These studies were the first to highlight an apoptosisindependent role for a caspase in regulating neural precursor cell formation in Drosophila. This process involves Droncmediated cleavage of Shaggy (Sgg46), which negatively regulates Wingless signaling required for SOP formation. ${ }^{80}$ In turn, Dronc activity is positively regulated by Drosophila $I_{\kappa} \mathrm{K}$, DmIKK, which degrades the caspase inhibitor protein DIAP1, to control SOP development. ${ }^{81}$
In mammals, caspase function in terminal differentiation has also been described in various cell types (Table 1), including keratinocytes, megakaryocytes, erythrocytes and lens cells. ${ }^{82}$ A non-apoptotic role for the key effector caspase, caspase-3, was identified in lens fiber formation. ${ }^{83}$ The process of differentiation of lens epithelial cell into a lens fiber involves enucleation (loss of nuclei), which was found to be caspase-3 dependent. ${ }^{83}$ Other cells that demonstrate enucletion during differentiation include RBCs and keratinocytes. Several caspases, including caspase-3, -2 , and -9 are transiently activated prior to enucleation during erythroid differentiation and involved cleavage of several proteins such as PARP, acinus and lamin B. ${ }^{84}$ Expression of active caspase- 3 was shown to be associated with cell proliferation and migration during neuronal differentiation. ${ }^{85}$ Furthermore, in a mouse model of stroke, cleaved caspase-3 levels were increased in neuronal precursor cells (NPCs) during stroke recovery, without any associated increase in apoptosis. ${ }^{86}$ Inhibition of caspase-3 activity significantly promoted the proliferation and migration of NPCs indicating that caspase-3 limits selfrenewal capacity of regenerating neurons. Mechanistically, this was attributed to the ability of caspase- 3 to reduce phosphorylation of Akt. ${ }^{86}$

Differentiation of muscle progenitor cells into myotubes and myofibres also requires caspase- $3 .^{87}$ Later studies demonstrated the involvement of caspase- 9 in this process. It was observed that depletion of caspase- 9 or overexpression of $\mathrm{Bcl}-\mathrm{xL}$ reduced caspase- 3 activation and this had a limiting effect on the differentiation of myoblasts. ${ }^{88}$

Osteogenic differentiation of mesenchymal stem cells involves caspase-3 activity, and caspase-3-deficient mice exhibit attenuated differentiation of the bone marrow stromal stem cells and consequently decreased bone mineral density. ${ }^{89}$ It is noteworthy that the process of normal osteoblast differentiation requires the transient and potent activation of other caspases, including caspase-8 and -2 , without any increase in osteoblast apoptotic cell death. ${ }^{90}$ Caspase-7 has an additional role in proper functioning of odontoblasts as caspase-7 knockout mice show reduced dental mineralization. ${ }^{91}$

A role for caspase- 3 in differentiation of embryonic stem cells (ESCs) and hematopoietic stem cells (HSCs) has also been reported, ${ }^{92,93}$ with caspase-3 deficiency-impeding differentiation

Table 1 Differentiation of many cell types involves caspases

\begin{tabular}{|c|c|c|c|}
\hline Progenitor cells & Caspase activation & Mechanism & Reference (s) \\
\hline Erythroid cells & Caspase-2, -3 and -9 & Cleavage of lamin B and acinus & 84 \\
\hline Keratinocytes & Caspase-3 & $\begin{array}{l}\text { Terminal differentiation of embryonic cells involving } \\
\text { Casp3-Notch1 mechanism }\end{array}$ & 102 \\
\hline \multirow[t]{2}{*}{ Lens cells } & Caspase-14 & $\begin{array}{l}\text { Caspase-14 induction and processing during differentiation } \\
\text { of keratinocytes }\end{array}$ & 98,99 \\
\hline & Caspase-3 & Lens fiber formation & 83 \\
\hline Muscle progenitor cell & Caspase-3 and -9 & Muscle fiber formation & 87,88 \\
\hline Bone marrow stromal stem cells & Caspase-3 & Osteoblasts and bone formation involving TGF $\beta$ signaling & 89 \\
\hline Osteoblasts & Caspase-2, -3 and -8 & Activation of caspases in differentiating cells & 90 \\
\hline Odontoblasts & Caspase-7 & Activation of caspase- 7 in bone-forming cells & 91 \\
\hline Monocytes (bone marrow) & Caspase- $3,-8$ and -9 & Macrophage formation & 94 \\
\hline Neurons & Caspase-3 & Neuronal differentiation, migration and plasticity & 85 \\
\hline Embryonic stem cells & Caspase-3 & Caspase-3-mediated cleavage of Nanog & 92 \\
\hline Haematopoietic stem cell & Caspase-3 & Maintenance of stem-cell quiescence and response to external stimuli & 93 \\
\hline
\end{tabular}


of these stem cell populations. Caspase activity is also required for macrophage colony-stimulating factor (M-CSF)-mediated differentiation of human peripheral blood monocytes. ${ }^{94}$ Deletion of caspase-8 in bone-marrow cells abrogates monocyte differentiation into macrophages. ${ }^{95}$ In addition, caspase-8mediated cleavage of RIP1, is required for downregulation of $\mathrm{NF}-\kappa \beta$ during macrophage differentiation. ${ }^{96}$

Caspase-14, unlike other caspases, is present only in terrestrial mammals ${ }^{97}$ and its expression is limited to epidermal tissue and epithelia, particularly the cornifying epithelia of the skin. ${ }^{98,99}$ In the skin caspase-14 is expression is restricted to differentiating keratinocytes and absent in proliferating keratinocytes. ${ }^{99,100}$ Caspase-14 was found to be involved in cornification, hydration and protection against UVB by correct processing and degradation of (pro)filaggrin. ${ }^{101}$ In addition to caspase-14, caspase-3 functions in the commitment stage of embryonic keratinocytes to terminal differentiation. ${ }^{102}$ During keratinocyte differentiation, caspase3 activity is induced following Notch 1 signaling and mediates cleavage and activation of $\mathrm{PKC}-\delta$, a positive regulator of keratinocyte differentiation. ${ }^{102}$ In support of this role, mice deficient for caspase-3 exhibit increased keratinocyte proliferation and deceased keratinocyte differentiation during embryogenesis. ${ }^{102}$ Altered caspase-14 has also been observed in inflammatory skin disorders such as psoriasis. ${ }^{103}$

\section{Caspases in Cell Proliferation and Tissue Regeneration}

Apoptosis is closely linked to the process of regeneration that is evolutionary conserved. Invertebrates such as Hydra ${ }^{104}$ and amphibians such as Xenopus show increased apoptosis during regeneration. ${ }^{105}$ MAPK signaling in dying cells activates Wnt-ligand secretion that drives this compensatory proliferation in surrounding cells. ${ }^{104,106}$

The process of 'compensatory proliferation' was originally defined in Drosophila-larval-imaginal tissues, which carry extensive regenerative capacity and cell proliferation to compensate for cell loss through damage or injury, and thereby maintain tissue size and shape. ${ }^{107}$ In the absence of effector-caspase activity these cells express high levels of activated Dronc but fail to die. Instead, Dronc activity is required for compensatory proliferation and functions to promote expression of the mitogens Wingless $(\mathrm{Wg})$ and Decapentaplegic (Dpp) to promote proliferation of neighboring cells. ${ }^{108-110}$ The effector caspases Drice and Dcp-1 can also induce compensatory proliferation in differentiating eye tissue, by activation of the Hedgehog signaling pathway. ${ }^{106}$ These studies demonstrated critical roles for caspases in coordinating both cell death and proliferation during development and regeneration, and provided the first in vivo evidence for a nonapoptotic function for an initiator-apoptotic caspase. ${ }^{109}$

Mammals have greatly reduced regenerative ability but some tissues, such as liver and skin undergo extensive regeneration. Both caspase-3- and -7-deficient mice have impaired liver regeneration and wound healing. ${ }^{111}$ Mechanistically, this was attributed to calcium-independent phospholipase $\mathrm{A} 2$ activity (iPLA $A_{2}$ ). Both caspase-3 and -7 cleave iPLA which increases secretion of arachidonic acid and lysophosphocholine that further induce the secretion of prostaglandin E2 $\left(\mathrm{PGE}_{2}\right)$, which then promotes stem cell proliferation, tissue regeneration and repair (Figure 4). ${ }^{111} \mathrm{PGE}_{2}$ also has been shown to interact with the Wnt pathway at the level of $\beta$-catenin destruction to control HSC formation in vivo. ${ }^{112}$ This highlights that caspases are capable of cell repair by modulating the

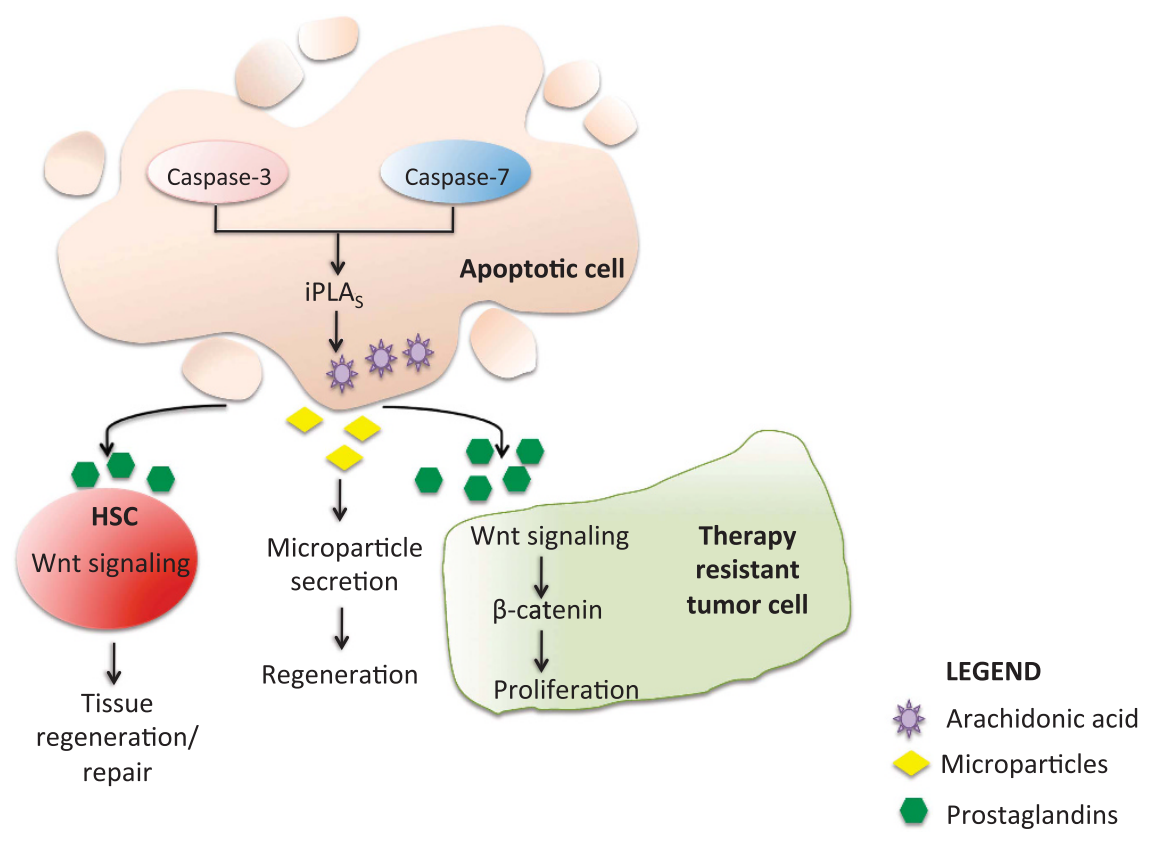

Figure 4 Caspase function in tissue regeneration and tumor cell proliferation. Activation of caspase-3 and -7 during radiotherapy or during tissue injury causes cleavage and activation of $\mathrm{PLA}_{2}$. This results in $\mathrm{AA}$ synthesis and subsequent $\mathrm{PGE}_{2}$ activation. The secreted $\mathrm{PGE}_{2}$ promotes proliferation in surrounding tumor cells by activation of Wnt $\beta$ catenin signaling. This facilitates tumor cell repopulation and acts as a limiting factor of effective therapy. Shedding of microparticles by apoptosing cells (pancreatic beta cells) stimulates proliferation/differentiation of neighboring cells through activation of regenerating (reg) genes. PGE $\mathrm{E}_{2}$ also interacts with Wnt signaling pathway to regulate stem cell/ progenitor formation and function. $\mathrm{IPLA}_{2}$, calcium-independent phospholipase A2; AA, arachidonic acid; PGE 2 , prostaglandin E2; HSC, hematopoietic stem cells 
secretion of paracrine factors independent of their cell death function. Further evidence for indirect control of cell growth and repair comes from another study involving conditional caspase-8 knockout mice. Mice with hepatocyte-specific deletion of caspase-8 (Casp8 $8^{\Delta \text { hepa }}$ ) show greatly improved liver regeneration due to increased $\mathrm{NF}_{\kappa} \mathrm{B}$ signaling ${ }^{113}$ and wound healing. Caspase-7 has another important role in osteogenesis. Adult caspase-7 knockout mice display reduced bone mineral density in endochondronal (long bones of limbs) and reduced bone volume (intramembraneous bones such as mandibular and alveolar bone). This is attributed to reduced gene expression of key bone-forming genes, Smad1 and Msx1. ${ }^{114}$

There is increasing evidence that mammalian caspases influence cell proliferation in a cell autonomous manner. Studies using caspase inhibitors, implicate a role for caspase8 in regulating lymphocyte proliferation. ${ }^{115-117}$ Caspase-8 deletion in T cells causes normal thymocyte development, but causes a substantial reduction in peripheral $T$ cells and impaired T-cell response to stimuli. ${ }^{118}$ Further with advancing age, these mice develop a lymphoproliferative phenotype characterized by lymphoadenopathy, splenomegaly and T-cell infiltration in several organs. ${ }^{119}$ These findings implicate an essential role for caspase-8 in T-cell homeostasis and immunity. In support of this role, patients with caspase-8 homozygous mutations have defects in lymphocytes and natural killer cell activation. ${ }^{120}$ FADD, is also essential for cytokine-induced proliferation of hematopoietic progenitor cells. ${ }^{121}$ These results, at least in part, could suggest that that loss of caspase-8 or FADD makes cells undergo necroptosis, rather than caspase-8 or FADD only having a direct effect on cell proliferation. However, the DISC complex comprising Fas/ FADD/c-FLIP $/$ caspase-8 also controls cell-cycle progression of hepatocytes following EGF stimulation. ${ }^{122}$ Like caspase-8, caspase- 1 and -6 have also been shown to regulate B-cell proliferation and maintain lymphocyte homeostasis. ${ }^{123,124}$

In a contrasting role, caspase-3-deficient B cells show hyperproliferation that is dependent on p21, a cyclindependent kinase inhibitor. ${ }^{125}$ Many caspase-3 substrates are cell-cycle regulators, including cyclin-dependent kinase (CDK) inhibitor p27, a mediator of lymphoid cell proliferation. ${ }^{126}$ Caspase-3 also cleaves p21 and this blocks p21 interaction with proliferating-cell nuclear antigen (PCNA), and consequently prevents cell proliferation.

\section{Caspases in Tumorigenesis}

The phenomena of cell growth and cell death are closely linked. Basically, tumors arise due to unregulated increase in proliferative activity although the cause for this is multifactorial. The most likely reason for increased cell number would be loss of cell death control. Several genes with well-established roles in cell death have tumor suppressor function. Activation of Bcl2 due to chromosomal translocation and gene amplification, blocks caspase activation and is frequently detected in nonHodgkin's lymphoma (NHL) and small cell lung cancers. ${ }^{127,128}$ Several clinical trials targeting Bcl-2 proteins as cancer therapeutics are ongoing. The cell death-inhibitor proteins, IAPs, are also promising targets for cancer research, as they suppress apoptosis either by inhibiting caspase activity or by modulating growth by targeting $\mathrm{NF}_{K} \mathrm{~B}$ signaling pathways. ${ }^{129}$ Caspases promote cell death and it would be expected therefore that loss of caspases promotes tumor development. They, however, are also involved in tumorigenesis through non-apoptotic pathways by affecting proliferation, invasion and migration. ${ }^{130}$

Caspase-1. Caspase-1 tumor-suppressor function has been widely demonstrated. Overexpression of caspase-1 enhances the sensitivity of androgen-independent prostate cancer cell lines, to irradiation-induced cell death. ${ }^{131}$ It is also known that caspase-1 is frequently downregulated in human cancers, particularly prostate cancer. ${ }^{132,133}$ When caspase1 -overexpressing renal cancer cells were injected into flanks of syngenic mice, not all mice developed solid tumors, while all control mice did. ${ }^{134}$ This was attributed to increased cell death following caspase-1 overexpression. It was also shown that while caspase-1 expression in renal cancer cell lines varies, tumor cells frequently have low caspase- 1 levels, and inducing gene expression by demethylation increases apoptosis and could prevent tumor growth. Further evidence for its role as a tumor suppressor comes from a mouse model of colitis-associated colorectal cancer. ${ }^{135}$ Caspase-1-deficient mice showed enhanced tumor formation, characterized by early stage increase in epithelial cell proliferation in the colon and reduced apoptosis during advanced disease stage. ${ }^{135}$ Recent studies have shown that originally generated caspase-1-deficient mice also harbor a mutation in the caspase-11 locus, which mediates LPS-induced lethality in these mice. ${ }^{136}$

Caspase-2. A tumor suppressor function for caspase-2 was first proposed based on an evidence that the human CASP2 gene region on chromosome $7 q$ is commonly deleted in leukemia. ${ }^{137}$ Although somatic mutations of CASP2 are not common in acute leukemia or solid cancers, ${ }^{138}$ the reduced expression of caspase- 2 is correlated with poor prognosis in some cancers, ${ }^{139,140}$ and high caspase-2 levels are associated with remission and survival in adults with ALL and AML. ${ }^{141}$ Furthermore, reduced expression and somatic missense mutations in CASP2 have been identified in some gastric and colorectal cancers. ${ }^{142}$

Studies using caspase-2 knockout mice and cells generated from these mice provided the first direct evidence that loss of caspase-2 enhances oncogene-induced cellular transformation and tumorigenic potential. ${ }^{143}$ Loss of caspase2 augments tumorigenesis in several different mouse tumor models, including E $\mu M y c$-driven lymphomagenesis, ${ }^{143}$ MMTV/ c-neu mammary carcinogenesis ${ }^{144}$ and $A T M^{-1-}$-mediated thymic lymphomagenesis. ${ }^{145}$ Although the mechanism by which caspase-2 functions as a tumor suppressor is still unclear, it does not appear to be a PIDDosome dependent. ${ }^{146}$ Loss of caspase-2 has been shown to impede undefined radiation (IR)-induced DNA damage response in primary murine embryonic fibroblasts by significantly reducing p53 activation and function. ${ }^{147}$ Recently, a tumor suppressor role for caspase- 2 was demonstrated in a mouse model of KRas-driven lung cancer. Tumors lacking caspase-2 responded better to chemotherapy, however, were more prone to relapse due to increased proliferation. It was observed that following DNA 
damage-mediated PIDD activation, caspase-2 cleaves mdm2, thus stabilizing p53 and preventing tumorigenesis. ${ }^{148}$ These studies suggest that caspase-2 cooperates with established tumor suppressors such as p53. However, caspase-2 deficiency does not influence IR-induced thymoma development in mice or affect spontaneous or IR-mediated thymoma in p53-null mice. ${ }^{146}$ In addition, loss of caspase-2 does not influence MCAdriven fibrosarcomas in mice. ${ }^{149}$ Interestingly, while caspase-2 acts as a tumor suppressor in cells with high c-myc expression, loss of Pidd had only slightly delayed tumor onset and had no additive effect. ${ }^{149}$ In contrast to a tumor suppressor function, caspase-2-deficient mice showed significantly delayed onset and development of $M Y C N$-mediated neuroblastoma, and high caspase-2 levels are associated with poor survival outcome in human neuroblastoma patients. ${ }^{150}$ Together these studies indicate that caspase-2 role as a tumor suppressor is tissue and context specific.

Caspase-3. Recently, Human Genome Epidemiology review and meta-analysis polymorphisms of CASP3 and CASP7 genes were found to be linked to cancer risk. ${ }^{151}$ Although somatic CASP3 mutations are rare in most tumors, ${ }^{152}$ $C A S P 3$-variant alleles have been detected in squamous cell carcinomas of the head and neck (SCCHN) and associated with increased risk of SCCHN. ${ }^{153}$ In addition, CASP3-variant alleles are associated with risk of endometrial cancer ${ }^{154}$ and $\mathrm{NHL}{ }^{155}$ and multiple myeloma. ${ }^{156}$ CASP3 polymorphisms in some lung cancer patients also show significantly decreased risk of disease. ${ }^{157}$ Although it was reported that caspase-3 expression is significantly reduced in breast cancer cells, cancer tissue and even in the normal parenchyma surrounding tumors, ${ }^{158}$ several groups have demonstrated the converse. Higher levels of caspase-3 protein were found in malignant, compared to nonmalignant breast tissue, and coincided with increased apoptosis. ${ }^{159}$ Indeed, it was observed that caspase- 3 is activated in dying tumor cells and causes increased secretion of $\mathrm{PGE}_{2}$ that results in tumor cell repopulation and resistance to radiotherapy. ${ }^{160}$ Further support to this study comes from human trials where two different cohorts of head and neck cancer patients and breast cancer patients, had high expression of active caspase-3 (cleaved caspase-3) and associated increased recurrence of the disease. This suggests that apoptosis is an essential aspect of tumor growth, and paracrine signals released by dying cells act to promote repopulation of these tumor cells and aids further growth.

Caspase-6 and -7. Mutations in CASP6 and CASP7 are rare in most human cancers. ${ }^{161}$ CASP6 mutations associated with reduced caspase- 6 expression have been detected in colonic and gastric cancers. ${ }^{142}$ Somatic mutations in CASP7 are associated with reduced apoptosis ${ }^{161}$ and have been detected in colon carcinoma, esophageal carcinomas and head/neck carcinomas, but not stomach, urinary bladder or lung cancers. ${ }^{161}$ CASP7 polymorphisms can promote susceptibility to lung cancer and endometrial cancer. ${ }^{162}$

Caspase-8. The connection between caspase-8 and carcinogenesis has been extensively studied. A comprehensive review on caspase-8 expression and different types of tumors is available in the Human Protein Atlas. ${ }^{163}$ The studies demonstrate that in most epithelial-derived cancers, such as colon carcinoma, gastric cancer and breast cancer that progress through multiple stages, the loss of caspase- 8 is a rare event and loss of expression is not detected. On the contrary, CASP 8 mutations have been detected in $5 \%$ of invasive colorectal carcinomas (but not adenomas), and are associated with dominant-negative caspase-8 function and decreased apoptosis. ${ }^{164}$ Somatic mutation of CASP8 has also been detected in hepatocellular carcinomas (HCCs) ${ }^{165}$ and advanced gastric cancers, ${ }^{166}$ and are associated with decreased cell death. ${ }^{165}$ Interestingly, a CASP8 polymorphism $(\mathrm{D} 302 \mathrm{H})$ is associated with significantly reduced overall risk breast cancer. ${ }^{167}$ In addition, malignant neuroendocrine tumors frequently show loss of caspase-8, such as neuroblastoma, ${ }^{168}$ primitive neuroectoderm tumors, ${ }^{169}$ medulloblastoma, ${ }^{170}$ relapsing glioblastoma ${ }^{171}$ and small cell lung carcinoma. ${ }^{172}$ Loss of caspase- 8 renders neuroblastoma cell lines resistant to apoptosis ${ }^{173}$ and enhances metastatic potential in chick embryos. ${ }^{174}$ In a mouse MYCN neuroblastoma model, deletion of caspase-8 promotes bone marrow metastasis. ${ }^{175}$ Increased caspase- 8 expression has been observed in many advanced-stage tumors suggesting that caspase-8 might promote metastasis. ${ }^{176}$ Further evidence in support of its metastatic role comes from the fact that caspase-8 has been shown to interact with the focal adhesion complex, ${ }^{177}$ thereby promote cell migration. The complex observations on caspase- 8 can be attributed to the fact that this caspase is involved in apoptosis and also protected against necroptosis. Hepatocyte-specific deletion of caspase-8 (Casp8 ${ }^{\Delta \text { hepa }}$ ) was found to be protective against hepatocarcinogenesis in $\mathrm{NEMO}^{\Delta \text { hepa }}$ mice that develop spontaneous $\mathrm{HCC}^{74}$ Thus caspase-8-induced apoptosis and compensatory proliferation is important in HCC progression, but the increased necrosis and liver damage observed in the absence of caspase-8, is insufficient for tumor progression.

Caspase-10. The absence of caspase-10 in mice has perhaps resulted in delay in understanding potential roles of this caspase. Nonetheless, inactivating CASP10 mutations have been detected in NHL. ${ }^{178}$ CASP10 mutations have also been detected in T-cell acute lymphoblastic leukemia and multiple myeloma, ${ }^{179}$ as well as colon, breast, lung, $\mathrm{HCCs}^{180}$ and gastric cancers. ${ }^{181}$ In a very interesting study, it has been shown that myeloma cells require caspase-10 for survival. Caspase-10 dimerizes with cFLIP to inhibit autophagy by preventing cleavage of the $\mathrm{Bcl}$-2-interacting protein BCLAF1. ${ }^{182}$

Caspase-14. Expression of caspase-14 is reduced in the colon, cervical and ovarian tumor tissue and associated with more advanced-stage cancers. ${ }^{183}$ However, ductal carcinomas showed increased caspase-14 levels compared to surrounding mammary tissue. ${ }^{183}$ Caspase-14 overexpression in a human salivary gland adenocarcinoma has been shown to promote growth inhibition and prevent tumorigenicity in athymic mice. ${ }^{184}$ 


\section{Caspase Activation During Aging}

Aging is often described as a process of progressive decline in function of organs/organism largely due to accumulation of damaged cells. Ever since caspases were discovered and apoptosis established as an intricate cell death mechanism, it was causally linked to organismal aging. Apoptosis was implicated in the aging process in two ways: by clearing multicellular organism of dysfunctional or unwanted cells, it maintains normal homeostasis; or by removing functionally important post-mitotic cells such as neurons or cardiac myocytes, it may hasten aging-associated pathologies.

Mutations in NALP3 gene, which increase caspase-1 activity and consequently IL-1 $\beta$ and IL-18, lead to systemic inflammatory diseases that increases during aging. ${ }^{185}$ Increase in oxidative stress and low-grade inflammation are the hallmarks of the aging process, which have been linked to caspase-1 activity. ${ }^{186}$ In another study, improvement in memory was observed in rats injected intracerebroventricularly with a caspase-1 inhibitor (Ac-YVAD-CMK), ${ }^{187}$ indicating that inhibition of caspase-1 can delay aging-associated pathologies.

Alzheimer's disease is an age-associated pathology and active caspase-6, which plays an important role in the etiology of this disease. ${ }^{188}$ Sarcopenia, age-related muscle loss, is associated with decreased differentiation of a population of stem cells, called satellite cells (SCs), into myofibrils. In a study, analyzing caspase activity in young and aged individuals, an increased rate of apoptosis and increased CASP2, CASP6, CASP7 and CASP9 levels in aged SCs, was observed, indicating an enhanced susceptibility of human SCs to undergo apoptosis with age. ${ }^{189}$ This would diminish the stem cell population and trigger increased muscle loss or damage.

Age-associated hearing loss occurs with accompanying cochlear degeneration and high levels of apoptosis. Calorie restriction, $\mathrm{CR}$, which is known to delay aging in mice and other laboratory animals prevented apoptosis and hearing loss. ${ }^{190}$ The underlying mechanism is reduced ROS and mitochondrial damage during CR. ${ }^{191}$ Another quality control process that declines with aging is the unfolded protein response (UPR). Aged mice fail to employ UPR, especially when sleep deprived and simultaneously showed increased caspase-12 activity and apoptosis. This was not observed in young mice and suggests increased caspase activity to compensate a poor ER-stressinduced adaptive response. ${ }^{192}$

Zhang et al. ${ }^{193}$ first demonstrated a role for caspase-2 in delaying aging. Latter it was shown that caspase-2-deficient mice have reduced antioxidant ability and experience increased oxidative stress that accounts for their shorter lifespan. ${ }^{193}$ Aged caspase-2 knockout mice tissues also exhibit increased oxidative DNA damage and double-strand DNA breaks $(\gamma \mathrm{H} 2 \mathrm{AX}){ }^{194}$ Paraquat-induced pulmonary lesions in aged caspase-2 knockout mice were more severe and associated with hepatocyte karyomegaly. ${ }^{195}$ It was recently shown that the increase in mitochondrial ROS in aged caspase-2 knockout mice is associated with mitochondrial complex-III activity. ${ }^{196}$ The early-aging phenotype observed in caspase-2 knockout is distinct and involves non-apoptotic properties of this protease including its role in oxidative stress. A proposed model depicting how presence or absence of caspases can lead to aging is shown in Figure 5.

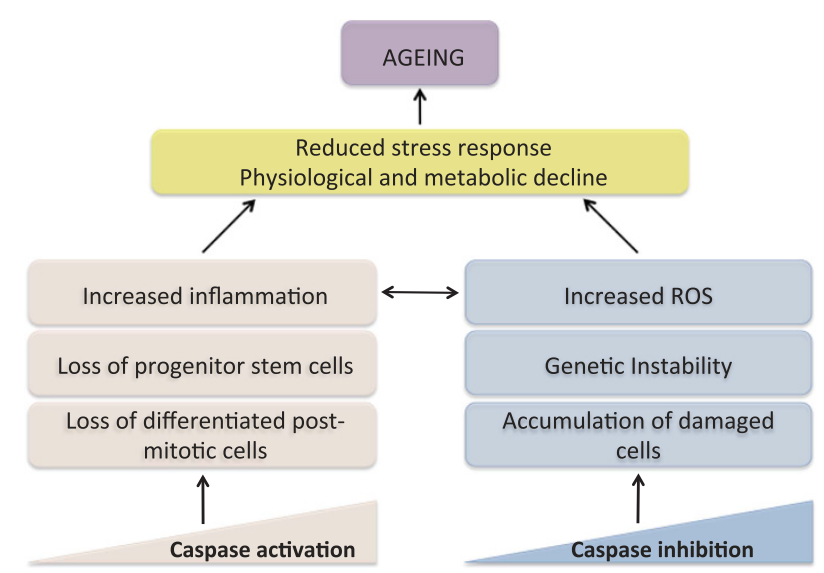

Figure 5 Caspase activation occurs during aging, which is normally accompanied by a general decline in stress tolerance and functional strength. On one hand, this increased caspase activity, accelerates aging by increasing inflammation (e.g., caspase-1). Increased activity of caspases also results in removal of stem cells (e.g., loss of satellite cells by caspase-6), while in conditions such as stroke/ischemia, it causes loss of highly differentiated cells such as neurons and cardiomyocytes (e.g., caspase-9), causing functional decline and reduced regenerative ability. In another alternate scenario, loss of apoptosis may also hasten the aging process by preventing removal of damaged cells, increasing genetic instability and oxidative stress (e.g., caspase-2)

\section{Caspases in Neural Development}

Apoptosis plays a crucial role during neural development both in embryos and during adult life. ${ }^{197}$ Caspase-3, -9 and Apaf-1 are involved in forebrain development as mice lacking these proteins show exencephaly and neural overgrowth, attributed to increased cell death both in NPCs and developing neurons. ${ }^{197}$ However, caspases also affect neural development in non-apoptotic manner (Table 2).

One such process is neuronal sculpting by dendrite pruning that results in removal of aberrant dendrites/axonal connections. Pioneering work in Drosophila revealed that Dronc is essential for dendrite pruning during larval development and the consequent formation of the adult nervous system. ${ }^{198}$ This process is dependent on ubiquitin-mediated degradation of DIAP1, to permit Dronc activation, and altered Dronc localization in axon and dendrites. ${ }^{198}$ Similar to apoptosis, the effector phase of pruning of dendrites involves cytoskeletal disruption, cell fragmentation and phagocytic clearance, indicating that Dronc activation may induce these morphological changes in the absence of cell death.

Recently, caspase-3 was found to control spine density and dendrite morphology without any observed increase in cell death. ${ }^{199}$ In support to these findings supernumerary spines have been reported in caspase-3 knockout mice. ${ }^{199}$ In a related study, caspase-2-deficient J20 APP transgenic mice did not show age-related reduction in cognitive function. This was attributed to an important role for caspse-2 in controlling dendrite spine density. ${ }^{200}$ Caspase- 2 was found to activate the RhoA/ROCK-II signaling pathway, leading to collapse of dendritic spines.

Caspases are also involved in axonal guidance and synaptogenesis. Mice lacking caspase- 9 and Apaf1 display misrouted axons, impaired synapse formation and defects in sensory neurons responsible for olfaction. However, no 
Table 2 Non-apoptotic roles of caspases in neuronal function

\begin{tabular}{|c|c|c|c|}
\hline Process & Caspase & Mechanism & Reference \\
\hline \multirow[t]{2}{*}{ Dendritic pruning } & Caspase-2 & Activation of Rho/ROCK-II & 200 \\
\hline & Caspase-3 & Activation of caspase-3 & 199 \\
\hline \multirow[t]{2}{*}{ Axon guidance and synaptogenesis } & $\begin{array}{l}\text { Caspase- } 3 \text { and }-6 \text { are involved in } \\
\text { axonal guidance and synapse } \\
\text { formation }\end{array}$ & $\begin{array}{l}\text { Mice lacking caspase- } 3 \text { and }-6 \text { have developmental } \\
\text { delay in pruning retinocollicular axons }\end{array}$ & 202 \\
\hline & $\begin{array}{l}\text { Caspase- } 9 \text { and Apaf regulate } \\
\text { synapse formation }\end{array}$ & $\begin{array}{l}\text { Casp }^{-/-} \text {and } \text { Apaf }^{-1-} \text { mice have misrouted axons, } \\
\text { impaired synapse and defects in olfaction. Cleavage } \\
\text { of semaphorin } 7 \mathrm{~A} \text { is vital for proper projection of axons }\end{array}$ & 201 \\
\hline Normal synaptic plasticity and function & Caspase-3 is important in LTD & Caspase- 3-mediated internalization of AMPA & 203 \\
\hline
\end{tabular}

defects in neuronal cell death were observed. ${ }^{201}$ The underlying mechanism involves caspase-9-mediated cleavage of an essential protein, semaphorin 7A that is crucial for proper projection of axons. ${ }^{201}$ Caspase- 3 and -6 have also been implicated in the process of axonal guidance. ${ }^{202}$

Normal brain functions depend on proper synaptic activity. Long-term potentiation (LTP) and long-term depression (LTD) are long-lasting modifications of synapses, in the hippocampus region. Caspase- 3 is essential for LTD. ${ }^{203}$ During LTD, AMPA receptor in the post-synaptic membrane is internalized and the process is facilitated by caspase- 3 and blocked by peptide inhibitors of caspase-3 and -9 . It is again worth noting that during LTD, transient caspase- 3 activation occurs without causing cell death. ${ }^{202}$

\section{Conclusions}

Ever since their discovery almost two decades ago, caspases have been shown to modulate cellular functions in more than one way. Although the mechanism and their activation platforms during cell death and apoptosis are well characterized, many of their nonapoptotic functions are poorly defined. Caspases mediate most of their activity by cleaving their target proteins and this substrate specificity guides cellular behavior. Several caspases are involved in tissue differentiation, cell proliferation, tumor formation and metastasis, determining immune response, synaptic plasticity, DNA damage and stress response, metabolism and aging. Although activation of caspases in some processes involves apoptosis/cell death, some others are independent of their apoptotic activity. Thus a better understanding of these functions may have much broader implications than previously thought. A better knowledge about caspase function may provide greatly improved strategies to design effective therapeutics in the area of inflammation, autoimmune disease and cancer.

\section{Conflict of Interest}

The authors declare no conflict of interest.

\begin{abstract}
Acknowledgements. Research work on caspase and cell death in our laboratory is supported by the National Health and Medical Research Council (NHMRC) of Australia project grants (1021456, 1041807 and 1043057), a Cancer Council Collaborative Research Fellowship to LD and a NHMRC Senior Principal Research Fellowship (1002863) to SK.
\end{abstract}

1. Galluzzi L, Bravo-San Pedro JM, Vitale I, Aaronson SA, Abrams JM, Adam D et al. Essential versus accessory aspects of cell death: recommendations of the NCCD 2015. Cell Death Differ 2015; 22: 58-73.
2. Kroemer G, Galluzzi L, Vandenabeele P, Abrams J, Alnemri ES, Baehrecke EH et al. Classification of cell death: recommendations of the Nomenclature Committee on Cell Death 2009. Cell Death Differ 2009; 16: 3-11.

3. Galluzzi L, Vitale I, Abrams JM, Alnemri ES, Baehrecke EH, Blagosklonny MV et al. Molecular definitions of cell death subroutines: recommendations of the Nomenclature Committee on Cell Death 2012. Cell Death Differ 2012; 19: 107-120.

4. Ellis HM, Horvitz HR. Genetic control of programmed cell death in the nematode C. elegans. Cell 1986; 44: 817-829.

5. Yuan J, Shaham S, Ledoux S, Ellis HM, Horvitz HR. The C. elegans cell death gene ced-3 encodes a protein similar to mammalian interleukin-1 beta-converting enzyme. Cell 1993; 75: 641-652.

6. Kumar S, Kinoshita M, Noda M, Copeland NG, Jenkins NA. Induction of apoptosis by the mouse Nedd2 gene, which encodes a protein similar to the product of the Caenorhabditis elegans cell death gene ced-3 and the mammalian IL-1 beta-converting enzyme. Genes Dev 1994; 8: 1613-1626.

7. Kumar S, Tomooka Y, Noda M. Identification of a set of genes with developmentally downregulated expression in the mouse brain. Biochem Biophys Res Commun 1992; 185: 1155-1161.

8. Eckhart L, Ballaun C, Hermann M, VandeBerg JL, Sipos W, Uthman A et al. Identification of novel mammalian caspases reveals an important role of gene loss in shaping the human caspase repertoire. Mol Biol Evol 2008; 25: 831-841.

9. Mcllwain DR, Berger T, Mak TW. Caspase functions in cell death and disease. Cold Spring Harb Perspect Biol 2013; 5: a008656.

10. Fischer $\mathrm{H}$, Koenig U, Eckhart L, Tschachler E. Human caspase 12 has acquired deleterious mutations. Biochem Biophys Res Commun 2002; 293: 722-726.

11. Hoste E, Kemperman P, Devos M, Denecker G, Kezic S, Yau N et al. Caspase-14 is required for filaggrin degradation to natural moisturizing factors in the skin. $J$ Invest Dermatol 2011; 131: 2233-2241.

12. Kumar S. Caspase function in programmed cell death. Cell Death Differ 2007; 14: 32-43.

13. Czabotar PE, Lessene G, Strasser A, Adams JM. Control of apoptosis by the BCL-2 protein family: implications for physiology and therapy. Nat Rev Mol Cell Biol 2014; 15: 49-63.

14. Gaur U, Aggarwal BB. Regulation of proliferation, survival and apoptosis by members of the TNF superfamily. Biochem Pharmacol 2003; 66: 1403-1408.

15. Li H, Zhu H, Xu CJ, Yuan J. Cleavage of BID by caspase 8 mediates the mitochondrial damage in the Fas pathway of apoptosis. Cell 1998; 94: 491-501.

16. Baliga $\mathrm{BC}$, Read $\mathrm{SH}$, Kumar $\mathrm{S}$. The biochemical mechanism of caspase-2 activation. Cell Death Differ 2004; 11: 1234-1241.

17. Butt AJ, Harvey NL, Parasivam G, Kumar S. Dimerization and autoprocessing of the Nedd2 (caspase-2) precursor requires both the prodomain and the carboxyl-terminal regions. J Biol Chem 1998; 273: 6763-6768.

18. Tinel A, Tschopp J. The PIDDosome, a protein complex implicated in activation of caspase2 in response to genotoxic stress. Science 2004; 304: 843-846.

19. Manzl C, Krumschnabel G, Bock F, Sohm B, Labi V, Baumgartner F et al. Caspase-2 activation in the absence of PIDDosome formation. J Cell Biol 2009; 185: 291-303.

20. Kumar S. Caspase 2 in apoptosis, the DNA damage response and tumour suppression: enigma no more? Nat Rev Cancer 2009; 9: 897-903.

21. Vandenabeele P, Galluzzi L, Vanden Berghe T, Kroemer G. Molecular mechanisms of necroptosis: an ordered cellular explosion. Nat Rev Mol Cell Biol 2010; 11: 700-714.

22. Vanlangenakker N, Vanden Berghe T, Vandenabeele P. Many stimuli pull the necrotic trigger, an overview. Cell Death Differ 2012; 19: 75-86.

23. Vanden Berghe $T$, Linkermann A, Jouan-Lanhouet $S$, Walczak $H$, Vandenabeele $P$. Regulated necrosis: the expanding network of non-apoptotic cell death pathways. Nat Rev Mol Cell Biol 2014; 15: 135-147.

24. Tenev T, Bianchi K, Darding M, Broemer M, Langlais C, Wallberg F et al. The ripoptosome, a signaling platform that assembles in response to genotoxic stress and loss of IAPs. Mol Cell 2011; 43: 432-448.

25. Ofengeim D, Yuan J. Regulation of RIP1 kinase signalling at the crossroads of inflammation and cell death. Nat Rev Mol Cell Biol 2013; 14: 727-736.

26. Rickard JA, O'Donnell JA, Evans JM, Lalaoui N, Poh AR, Rogers T et al. RIPK1 regulates RIPK3-MLKL-driven systemic inflammation and emergency hematopoiesis. Cell 2014; 157 : $1175-1188$. 
27. Degterev A, Hitomi J, Germscheid M, Ch'en IL, Korkina O, Teng X et al. Identification of RIP1 kinase as a specific cellular target of necrostatins. Nat Chem Biol 2008; 4: 313-321.

28. Takahashi N, Vereecke L, Bertrand MJ, Duprez L, Berger SB, Divert T et al. RIPK1 ensures intestinal homeostasis by protecting the epithelium against apoptosis. Nature 2014; 513: 95-99.

29. Dannappel M, Vlantis K, Kumari S, Polykratis A, Kim C, Wachsmuth L et al. RIPK1 maintains epithelial homeostasis by inhibiting apoptosis and necroptosis. Nature 2014; 513 : 90-94.

30. Monack DM, Raupach B, Hromockyj AE, Falkow S. Salmonella typhimurium invasion induces apoptosis in infected macrophages. Proc Natl Acad Sci USA 1996; 93: 9833-9838.

31. Zychlinsky A, Prevost MC, Sansonetti PJ. Shigella flexneri induces apoptosis in infected macrophages. Nature 1992; 358: 167-169.

32. Cookson BT, Brennan MA. Pro-inflammatory programmed cell death. Trends Microbio 2001; 9: 113-114

33. Brennan MA, Cookson BT. Salmonella induces macrophage death by caspase1-dependent necrosis. Mol Microbiol 2000; 38: 31-40.

34. Miao EA, Rajan JV, Aderem A. Caspase-1-induced pyroptotic cell death. Immunol Rev 2011; 243: 206-214.

35. Bergsbaken T, Fink SL, Cookson BT. Pyroptosis: host cell death and inflammation. Nat Rev Microbiol 2009; 7: 99-109.

36. Miao EA, Leaf IA, Treuting PM, Mao DP, Dors M, Sarkar A et al. Caspase-1-induced pyroptosis is an innate immune effector mechanism against intracellular bacteria. Nat Immunol 2010; 11: 1136-1142.

37. Bergsbaken T, Cookson BT. Macrophage activation redirects yersinia-infected host cell death from apoptosis to caspase-1-dependent pyroptosis. PLoS Pathog 2007; 3: e161.

38. Maiuri MC, Zalckvar E, Kimchi A, Kroemer G. Self-eating and self-killing: crosstalk between autophagy and apoptosis. Nat Rev Mol Cell Biol 2007; 8: 741-752.

39. Denton D, Nicolson S, Kumar S. Cell death by autophagy: facts and apparent artefacts. Cell Death Differ 2012; 19: 87-95.

40. Cho DH, Jo YK, Hwang JJ, Lee YM, Roh SA, Kim JC. Caspase-mediated cleavage of ATG6/Beclin-1 links apoptosis to autophagy in HeLa cells. Cancer Lett 2009; 274: 95-100.

41. Zhu Y, Zhao L, Liu L, Gao P, Tian W, Wang X et al. Beclin 1 cleavage by caspase-3 inactivates autophagy and promotes apoptosis. Protein Cell 2010; 1: 468-477.

42. Norman JM, Cohen GM, Bampton ET. The in vitro cleavage of the hAtg proteins by cell death proteases. Autophagy 2010; 6: 1042-1056.

43. Oral O, Oz-Arslan D, Itah Z, Naghavi A, Deveci R, Karacali S et al. Cleavage of Atg3 protein by caspase-8 regulates autophagy during receptor-activated cell death. Apoptosis 2012; 17: $810-820$.

44. DeVorkin L, Gorski SM. A mitochondrial-associated link between an effector caspase and autophagic flux. Autophagy 2014; 10: 1866-1867

45. Tiwari M, Sharma LK, Vanegas D, Callaway DA, Bai Y, Lechleiter JD et al. A nonapoptotic role for CASP2/caspase 2: modulation of autophagy. Autophagy 2014; 10: 1054-1070.

46. Pagliarini V, Wirawan E, Romagnoli A, Ciccosanti F, Lisi G, Lippens S et al. Proteolysis of Ambra1 during apoptosis has a role in the inhibition of the autophagic pro-survival response. Cell Death Differ 2012; 19: 1495-1504

47. Betin VM, Lane JD. Atg4D at the interface between autophagy and apoptosis. Autophagy 2009; 5: 1057-1059.

48. Castedo M, Perfettini JL, Roumier T, Valent A, Raslova H, Yakushijin $\mathrm{K}$ et al. Mitotic catastrophe constitutes a special case of apoptosis whose suppression entails aneuploidy. Oncogene 2004; 23: 4362-4370.

49. Thornberry NA, Bull HG, Calaycay JR, Chapman KT, Howard AD, Kostura MJ et al. A nove heterodimeric cysteine protease is required for interleukin-1 beta processing in monocytes. Nature 1992; 356: 768-774.

50. Ghayur T, Banerjee S, Hugunin M, Butler D, Herzog L, Carter A et al. Caspase-1 processes IFN-gamma-inducing factor and regulates LPS-induced IFN-gamma production. Nature 1997; 386: 619-623.

51. Kuida K, Lippke JA, Ku G, Harding MW, Livingston DJ, Su MS et al. Altered cytokine export and apoptosis in mice deficient in interleukin-1 beta converting enzyme. Science 1995; 267 2000-2003.

52. Li P, Allen H, Banerjee S, Franklin S, Herzog L, Johnston C et al. Mice deficient in IL-1 beta-converting enzyme are defective in production of mature IL-1 beta and resistant to endotoxic shock. Cell 1995; 80: 401-411.

53. Siegmund B. Interleukin-1beta converting enzyme (caspase-1) in intestinal inflammation. Biochem Pharmacol 2002; 64: 1-8.

54. Stoven S, Silverman N, Junell A, Hedengren-Olcott M, Erturk D, Engstrom $Y$ et al. Caspase-mediated processing of the Drosophila NF-kappaB factor Relish. Proc Natl Acad Sci USA 2003; 100: 5991-5996

55. Tanji T, Ip YT. Regulators of the Toll and Imd pathways in the Drosophila innate immune response. Trends Immunol 2005; 26: 193-198.

56. Martinon F, Agostini L, Meylan E, Tschopp J. Identification of bacterial muramyl dipeptide as activator of the NALP3/cryopyrin inflammasome. Curr Biol 2004; 14: 1929-1934.

57. Wang S, Miura M, Jung YK, Zhu H, Li E, Yuan J. Murine caspase-11, an ICE-interacting protease, is essential for the activation of ICE. Cell 1998: 92: 501-509.

58. Shi J, Zhao Y, Wang Y, Gao W, Ding J, Li P et al. Inflammatory caspases are innate immune receptors for intracellular LPS. Nature 2014; 514: 187-192.

59. Scott AM, Saleh M. The inflammatory caspases: guardians against infections and sepsis. Cell Death Differ 2007; 14: 23-31.
60. Saleh M, Mathison JC, Wolinski MK, Bensinger SJ, Fitzgerald P, Droin N et al. Enhanced bacterial clearance and sepsis resistance in caspase-12-deficient mice. Nature 2006; 440 : 1064-1068.

61. Saleh M, Vaillancourt JP, Graham RK, Huyck M, Srinivasula SM, Alnemri ES et al. Differential modulation of endotoxin responsiveness by human caspase-12 polymorphisms. Nature 2004; 429: 75-79.

62. Martinon F, Burns K, Tschopp J. The inflammasome: a molecular platform triggering activation of inflammatory caspases and processing of prolL-beta. Mol Cell 2002; 10: 417-426.

63. Agostini L, Martinon F, Burns K, McDermott MF, Hawkins PN, Tschopp J. NALP3 forms an IL-1beta-processing inflammasome with increased activity in Muckle-Wells autoinflammatory disorder. Immunity 2004; 20: 319-325.

64. Lamkanfi M, Dixit VM. Mechanisms and functions of inflammasomes. Cell 2014; 157: 1013-1022.

65. Mariathasan S, Weiss DS, Newton K, McBride J, O'Rourke K, Roose-Girma M et al. Cryopyrin activates the inflammasome in response to toxins and ATP. Nature 2006; 440: 228-232.

66. Hornung V, Latz E. Intracellular DNA recognition. Nat Rev Immunol 2010; 10: 123-130.

67. Bouchier-Hayes L, Conroy H, Egan H, Adrain C, Creagh EM, MacFarlane M et al. CARDINAL, a novel caspase recruitment domain protein, is an inhibitor of multiple NFkappa B activation pathways. J Biol Chem 2001; 276: 44069-44077.

68. Shimada K, Crother TR, Arditi M. Innate immune responses to Chlamydia pneumoniae infection: role of TLRs, NLRs, and the inflammasome. Microbes Infect 2012; 14: 1301-1307.

69. Allam R, Lawlor KE, Yu EC, Mildenhall AL, Moujalled DM, Lewis RS et al. Mitochondria apoptosis is dispensable for NLRP3 inflammasome activation but non-apoptotic caspase-8 is required for inflammasome priming. EMBO Rep 2014; 15: 982-990.

70. Vince JE, Wong WW, Gentle I, Lawlor KE, Allam R, O'Reilly L et al. Inhibitor of apoptosis proteins limit RIP3 kinase-dependent interleukin-1 activation. Immunity 2012; 36: 215-227.

71. Maelfait J, Vercammen E, Janssens S, Schotte P, Haegman M, Magez S et al. Stimulation of Toll-like receptor 3 and 4 induces interleukin-1beta maturation by caspase-8. J Exp Med 2008; 205: 1967-1973

72. Kovalenko A, Kim JC, Kang TB, Rajput A, Bogdanov K, Dittrich-Breiholz O et al. Caspase-8 deficiency in epidermal keratinocytes triggers an inflammatory skin disease. J Exp Med 2009; 206: 2161-2177.

73. Ben Moshe T, Barash H, Kang TB, Kim JC, Kovalenko A, Gross E et al. Role of caspase-8 in hepatocyte response to infection and injury in mice. Hepatology 2007; 45: 1014-1024.

74. Liedtke C, Bangen JM, Freimuth J, Beraza N, Lambertz D, Cubero FJ et al. Loss of caspase- 8 protects mice against inflammation-related hepatocarcinogenesis but induces non-apoptotic liver injury. Gastroenterology 2011; 141: 2176-2187.

75. Rajput A, Kang TB, Bogdanov K, Kim JC, Ben-Moshe T, Kovalenko A et al. Anti-inflammatory functions of caspase-8. Adv Exp Med Biol 2011; 691: 253-260.

76. Lamkanfi M, Kanneganti TD, Franchi L, Nunez G. Caspase-1 inflammasomes in infection and inflammation. J Leukoc Biol 2007; 82: 220-225.

77. Mills K, Daish T, Harvey KF, Pfleger CM, Hariharan IK, Kumar S. The Drosophila melanogaster Apaf-1 homologue ARK is required for most, but not all, programmed cell death. J Cell Biol 2006; 172: 809-815.

78. Daish TJ, Mills K, Kumar S. Drosophila caspase DRONC is required for specific developmental cell death pathways and stress-induced apoptosis. Dev Cell 2004; 7: 909-915.

79. Kanuka H, Sawamoto K, Inohara N, Matsuno K, Okano H, Miura M. Control of the cell death pathway by Dapaf-1, a Drosophila Apaf-1/CED-4-related caspase activator. Mol Cell 1999; 4: 757-769.

80. Kanuka H, Kuranaga E, Takemoto K, Hiratou T, Okano H, Miura M. Drosophila caspase transduces Shaggy/GSK-3beta kinase activity in neural precursor development. EMBO J 2005; 24: 3793-3806

81. Kuranaga E, Kanuka H, Tonoki A, Takemoto K, Tomioka T, Kobayashi M et al. Drosophila IKK-related kinase regulates nonapoptotic function of caspases via degradation of IAPs. Cell 2006; 126: 583-596.

82. Lamkanfi M, Declercq W, Vanden Berghe $T$, Vandenabeele P. Caspases leave the beaten track: caspase-mediated activation of NF-kappaB. J Cell Biol 2006; 173: 165-171.

83. Ishizaki $\mathrm{Y}$, Jacobson MD, Raff MC. A role for caspases in lens fiber differentiation. J Cell Biol 1998; 140: 153-158.

84. Zermati Y, Garrido C, Amsellem S, Fishelson S, Bouscary D, Valensi F et al. Caspase activation is required for terminal erythroid differentiation. J Exp Med 2001; 193: 247-254.

85. Yan XX, Najbauer J, Woo CC, Dashtipour K, Ribak CE, Leon M. Expression of active caspase-3 in mitotic and postmitotic cells of the rat forebrain. J Comp Neurol 2001; 433: 4-22

86. Fan $W$, Dai $Y, X u H$, Zhu $X$, Cai $P$, Wang $L$ et al. Caspase-3 modulates regenerative response after stroke. Stem Cells 2014; 32: 473-486.

87. Fernando P, Kelly JF, Balazsi K, Slack RS, Megeney LA. Caspase 3 activity is required for skeletal muscle differentiation. Proc Natl Acad Sci USA 2002; 99: 11025-11030.

88. Murray TV, McMahon JM, Howley BA, Stanley A, Ritter T, Mohr A et al. A non-apoptotic role for caspase-9 in muscle differentiation. J Cell Sci 2008: 121: 3786-3793.

89. Miura M, Chen XD, Allen MR, Bi Y, Gronthos S, Seo BM et al. A crucial role of caspase-3 in osteogenic differentiation of bone marrow stromal stem cells. J Clin Invest 2004; 114: 1704-1713. 
90. Mogi M, Togari A. Activation of caspases is required for osteoblastic differentiation. J Biol Chem 2003; 278: 47477-47482.

91. Matalova E, Lesot H, Svandova E, Vanden Berghe T, Sharpe PT, Healy C et al. Caspase-7 participates in differentiation of cells forming dental hard tissues. Dev Growth Differ 2013; 55: 615-621.

92. Fujita J, Crane AM, Souza MK, Dejosez M, Kyba M, Flavell RA et al. Caspase activity mediates the differentiation of embryonic stem cells. Cell Stem Cell 2008; 2: 595-601.

93. Janzen V, Fleming HE, Riedt T, Karlsson G, Riese MJ, Lo Celso C et al. Hematopoietic stem cell responsiveness to exogenous signals is limited by caspase-3. Cell Stem Cell 2008; 2: 584-594

94. Sordet O, Rebe C, Plenchette S, Zermati Y, Hermine O, Vainchenker W et al. Specific involvement of caspases in the differentiation of monocytes into macrophages. Blood 2002; 100: 4446-4453.

95. Kang TB, Ben-Moshe T, Varfolomeev EE, Pewzner-Jung Y, Yogev N, Jurewicz A et al. Caspase-8 serves both apoptotic and nonapoptotic roles. J Immunol 2004; 173: 2976-2984.

96. Rebe C, Cathelin S, Launay S, Filomenko R, Prevotat L, L'Ollivier C et al. Caspase-8 prevents sustained activation of NF-kappaB in monocytes undergoing macrophagic differentiation. Blood 2007; 109: 1442-1450.

97. Lamkanfi M, Declercq W, Kalai M, Saelens X, Vandenabeele P. Alice in caspase land. A phylogenetic analysis of caspases from worm to man. Cell Death Differ 2002; 9: 358-361.

98. Eckhart L, Declercq W, Ban J, Rendl M, Lengauer B, Mayer C et al. Terminal differentiation of human keratinocytes and stratum corneum formation is associated with caspase-14 activation. J Invest Dermatol 2000; 115: 1148-1151.

99. Lippens S, Kockx M, Knaapen M, Mortier L, Polakowska R, Verheyen A et al. Epidermal differentiation does not involve the pro-apoptotic executioner caspases, but is associated with caspase-14 induction and processing. Cell Death Differ 2000; 7: 1218-1224.

100. Rendl M, Ban J, Mrass P, Mayer C, Lengauer B, Eckhart L et al. Caspase-14 expression by epidermal keratinocytes is regulated by retinoids in a differentiation-associated manner. $J$ Invest Dermatol 2002; 119: 1150-1155.

101. Denecker G, Hoste E, Gilbert B, Hochepied T, Ovaere P, Lippens S et al. Caspase-14 protects against epidermal UVB photodamage and water loss. Nat Cell Biol 2007; 9: $666-674$.

102. Okuyama R, Nguyen BC, Talora C, Ogawa E, Tommasi di Vignano A, Lioumi M et al. High commitment of embryonic keratinocytes to terminal differentiation through a Notch1-caspase 3 regulatory mechanism. Dev Cell 2004; 6: 551-562.

103. Hsu S, Dickinson D, Borke J, Walsh DS, Wood J, Qin H et al. Green tea polyphenol induces caspase 14 in epidermal keratinocytes via MAPK pathways and reduces psoriasiform lesions in the flaky skin mouse model. Exp Dermatol 2007; 16: 678-684.

104. Chera S, Ghila L, Dobretz K, Wenger Y, Bauer C, Buzgariu W et al. Apoptotic cells provide an unexpected source of Wnt3 signaling to drive hydra head regeneration. Dev Cell 2009; 17: 279-289.

105. Tseng AS, Adams DS, Qiu D, Koustubhan P, Levin M. Apoptosis is required during early stages of tail regeneration in Xenopus laevis. Dev Biol 2007; 301: 62-69.

106. Fan Y, Bergmann A. Distinct mechanisms of apoptosis-induced compensatory proliferation in proliferating and differentiating tissues in the Drosophila eye. Dev Cell 2008; 14: 399-410.

107. Milan M, Campuzano S, Garcia-Bellido A. Developmental parameters of cell death in the wing disc of Drosophila. Proc Natl Acad Sci USA 1997; 94: 5691-5696.

108. Wells BS, Yoshida E, Johnston LA. Compensatory proliferation in Drosophila imaginal discs requires Dronc-dependent p53 activity. Curr Biol 2006; 16: 1606-1615.

109. Kondo S, Senoo-Matsuda N, Hiromi Y, Miura M. DRONC coordinates cell death and compensatory proliferation. Mol Cell Biol 2006; 26: 7258-7268.

110. Huh JR, Guo M, Hay BA. Compensatory proliferation induced by cell death in the Drosophila wing disc requires activity of the apical cell death caspase Dronc in a nonapoptotic role. Curr Biol 2004; 14: 1262-1266.

111. Li F, Huang Q, Chen J, Peng Y, Roop DR, Bedford JS et al. Apoptotic cells activate the 'phoenix rising' pathway to promote wound healing and tissue regeneration. Sci Signal 2010; 3: ra13.

112. Goessling W, North TE, Loewer S, Lord AM, Lee S, Stoick-Cooper CL et al. Genetic interaction of PGE2 and Wnt signaling regulates developmental specification of stem cells and regeneration. Cell 2009; 136: 1136-1147.

113. Freimuth J, Bangen JM, Lambertz D, Hu W, Nevzorova YA, Sonntag R et al. Loss of caspase- 8 in hepatocytes accelerates the onset of liver regeneration in mice through premature nuclear factor kappa B activation. Hepatology 2013; 58: 1779-1789.

114. Svandova E, Lesot H, Vanden Berghe T, Tucker AS, Sharpe PT, Vandenabeele $P$ et al. Non-apoptotic functions of caspase-7 during osteogenesis. Cell Death Dis 2014; 5: e1366.

115. Alam A, Cohen LY, Aouad S, Sekaly RP. Early activation of caspases during T lymphocyte stimulation results in selective substrate cleavage in nonapoptotic cells. J Exp Med 1999; 190: $1879-1890$.

116. Kennedy NJ, Kataoka T, Tschopp J, Budd RC. Caspase activation is required for T cell proliferation. J Exp Med 1999; 190: 1891-1896.

117. Lens SM, Kataoka T, Fortner KA, Tinel A, Ferrero I, MacDonald RH et al. The caspase 8 inhibitor c-FLIP(L) modulates T-cell receptor-induced proliferation but not activation-induced cell death of lymphocytes. Mol Cell Biol 2002; 22: 5419-5433.

118. Salmena L, Lemmers B, Hakem A, Matysiak-Zablocki E, Murakami K, Au PY et al. Essential role for caspase 8 in T-cell homeostasis and T-cell-mediated immunity. Genes Dev 2003; 17: 883-895.
119. Salmena L, Hakem R. Caspase-8 deficiency in T cells leads to a lethal lymphoinfiltrative immune disorder. J Exp Med 2005; 202: 727-732.

120. Chun HJ, Zheng L, Ahmad M, Wang J, Speirs CK, Siegel RM et al. Pleiotropic defects in lymphocyte activation caused by caspase-8 mutations lead to human immunodeficiency. Nature 2002; 419: 395-399.

121. Pellegrini M, Bath S, Marsden VS, Huang DC, Metcalf D, Harris AW et al. FADD and caspase-8 are required for cytokine-induced proliferation of hemopoietic progenitor cells. Blood 2005; 106: 1581-1589.

122. Gilot D, Serandour AL, llyin GP, Lagadic-Gossmann D, Loyer P, Corlu A et al. A role for caspase-8 and c-FLIPL in proliferation and cell-cycle progression of primary hepatocytes. Carcinogenesis 2005; 26: 2086-2094.

123. Beisner DR, Ch'en IL, Kolla RV, Hoffmann A, Hedrick SM. Cutting edge: innate immunity conferred by B cells is regulated by caspase-8. J Immunol 2005; 175: 3469-3473.

124. Olson NE, Graves JD, Shu GL, Ryan EJ, Clark EA. Caspase activity is required for stimulated B lymphocytes to enter the cell cycle. J Immunol 2003; 170: 6065-6072.

125. Woo M, Hakem R, Furlonger C, Hakem A, Duncan GS, Sasaki T et al. Caspase-3 regulates cell cycle in B cells: a consequence of substrate specificity. Nat Immunol 2003; 4: 1016-1022.

126. Frost V, Al-Mehairi S, Sinclair AJ. Exploitation of a non-apoptotic caspase to regulate the abundance of the cdkl p27(KIP1) in transformed lymphoid cells. Oncogene 2001; 20 : 2737-2748.

127. Tsujimoto $\mathrm{Y}$, Cossman J, Jaffe $\mathrm{E}$, Croce $\mathrm{CM}$. Involvement of the bcl-2 gene in human follicular lymphoma. Science 1985; 228: 1440-1443.

128. Monni O, Joensuu H, Franssila K, Klefstrom J, Alitalo K, Knuutila S. BCL2 overexpression associated with chromosomal amplification in diffuse large B-cell lymphoma. Blood 1997; 90: 1168-1174.

129. Hunter AM, LaCasse EC, Korneluk RG. The inhibitors of apoptosis (IAPs) as cancer targets. Apoptosis 2007; 12: 1543-1568.

130. Jager R, Zwacka RM. The enigmatic roles of caspases in tumor development. Cancers (Basel) 2010; 2: 1952-1979.

131. Winter RN, Rhee JG, Kyprianou N. Caspase-1 enhances the apoptotic response of prostate cancer cells to ionizing radiation. Anticancer Res 2004; 24: 1377-1386.

132. Ummanni R, Lehnigk U, Zimmermann U, Woenckhaus C, Walther R, Giebel J. Immunohistochemical expression of caspase- 1 and -9 , uncleaved caspase-3 and -6 , cleaved caspase- 3 and -6 as well as Bcl-2 in benign epithelium and cancer of the prostate. Exp Ther Med 2010; 1: 47-52.

133. Winter RN, Kramer A, Borkowski A, Kyprianou N. Loss of caspase-1 and caspase-3 protein expression in human prostate cancer. Cancer Res 2001; 61: 1227-1232.

134. Ueki T, Takeuchi T, Nishimatsu H, Kajiwara T, Moriyama N, Narita $Y$ et al. Silencing of the caspase-1 gene occurs in murine and human renal cancer cells and causes solid tumor growth in vivo. Int J Cancer 2001; 91: 673-679.

135. Hu B, Elinav E, Huber S, Booth CJ, Strowig T, Jin C et al. Inflammation-induced tumorigenesis in the colon is regulated by caspase-1 and NLRC4. Proc Natl Acad Sci USA 2010; 107: 21635-21640.

136. Kayagaki N, Warming S, Lamkanfi M, Vande Walle L, Louie S, Dong J et al. Non-canonical inflammasome activation targets caspase-11. Nature 2011; 479: 117-121.

137. Kumar S, White DL, Takai S, Turczynowicz S, Juttner CA, Hughes TP. Apoptosis regulatory gene NEDD2 maps to human chromosome segment $7 q 34-35$, a region frequently affected in haematological neoplasms. Hum Genet 1995; 95: 641-644.

138. Kim MS, Chung NG, Yoo NJ, Lee SH. Somatic mutation of proapoptotic caspase-2 gene is rare in acute leukemias and common solid cancers. Eur J Haematol 2011; 86: 449-450.

139. Hofmann WK, de Vos S, Tsukasaki K, Wachsman W, Pinkus GS, Said JW et al. Altered apoptosis pathways in mantle cell lymphoma detected by oligonucleotide microarray. Blood 2001; 98: 787-794.

140. Holleman A, den Boer ML, Kazemier KM, Beverloo HB, von Bergh AR, Janka-Schaub GE et al. Decreased PARP and procaspase-2 protein levels are associated with cellular drug resistance in childhood acute lymphoblastic leukemia. Blood 2005; 106: 1817-1823.

141. Estrov Z, Thall PF, Talpaz M, Estey EH, Kantarjian HM, Andreeff M et al. Caspase 2 and caspase 3 protein levels as predictors of survival in acute myelogenous leukemia. Blood 1998; 92: 3090-3097.

142. Yoo NJ, Lee JW, Kim YJ, Soung YH, Kim SY, Nam SW et al. Loss of caspase-2, -6 and -7 expression in gastric cancers. APMIS 2004; 112: 330-335.

143. Ho LH, Taylor R, Dorstyn L, Cakouros D, Bouillet $\mathrm{P}$, Kumar S. A tumor suppressor function for caspase-2. Proc Natl Acad Sci USA 2009; 106: 5336-5341.

144. Parsons MJ, McCormick L, Janke L, Howard A, Bouchier-Hayes L, Green DR. Genetic deletion of caspase-2 accelerates MMTV/c-neu-driven mammary carcinogenesis in mice. Cell Death Differ 2013; 20: 1174-1182.

145. Puccini J, Shalini S, Voss AK, Gatei M, Wilson CH, Hiwase DK et al. Loss of caspase-2 augments lymphomagenesis and enhances genomic instability in Atm-deficient mice. Proc Natl Acad Sci USA 2013; 110: 19920-19925.

146. Manzl C, Fava LL, Krumschnabel G, Peintner L, Tanzer MC, Soratroi $C$ et al. Death of p53-defective cells triggered by forced mitotic entry in the presence of DNA damage is not uniquely dependent on Caspase-2 or the PIDDosome. Cell Death Dis 2013; 4: e942.

147. Dorstyn L, Puccini J, Wilson CH, Shalini S, Nicola M, Moore S et al. Caspase-2 deficiency promotes aberrant DNA-damage response and genetic instability. Cell Death Differ 2012; 19: $1288-1298$. 
148. Terry MR, Arya R, Mukhopadhyay A, Berrett KC, Clair PM, Witt B et al. Caspase-2 impacts lung tumorigenesis and chemotherapy response in vivo. Cell Death Differ 2014 e-pub ahead of print 10 October 2014; doi:10.1038/cdd.2014.159.

149. Manzl C, Peintner L, Krumschnabel G, Bock F, Labi V, Drach M et al. PIDDosomeindependent tumor suppression by caspase-2. Cell Death Differ 2012; 19: 1722-1732.

150. Dorstyn L, Puccini J, Nikolic A, Shalini S, Wilson CH, Norris MD et al. An unexpected role for caspase-2 in neuroblastoma. Cell Death Dis 2014; 5: e1383.

151. Yan S, Li YZ, Zhu XW, Liu CL, Wang P, Liu YL. HuGE systematic review and meta-analysis demonstrate association of CASP-3 and CASP-7 genetic polymorphisms with cancer risk Genet Mol Res 2013; 12: 1561-1573.

152. Soung YH, Lee JW, Kim SY, Park WS, Nam SW, Lee JY et al. Somatic mutations of CASP3 gene in human cancers. Hum Genet 2004; 115: 112-115.

153. Chen $\mathrm{K}$, Zhao H, Hu Z, Wang LE, Zhang W, Sturgis EM et al. CASP3 polymorphisms and risk of squamous cell carcinoma of the head and neck. Clin Cancer Res 2008: 14: 6343-6349.

154. Xu HL, Xu WH, Cai Q, Feng M, Long J, Zheng W et al. Polymorphisms and haplotypes in the caspase-3, caspase-7, and caspase-8 genes and risk for endometrial cancer: a population-based, case-control study in a Chinese population. Cancer Epidemio Biomarkers Prev 2009; 18: 2114-2122.

155. Lan Q, Morton LM, Armstrong B, Hartge P, Menashe I, Zheng T et al. Genetic variation in caspase genes and risk of non-Hodgkin lymphoma: a pooled analysis of 3 populationbased case-control studies. Blood 2009; 114: 264-267.

156. Hosgood HD 3rd, Baris D, Zhang Y, Zhu Y, Zheng T, Yeager M et al. Caspase polymorphisms and genetic susceptibility to multiple myeloma. Hematol Oncol 2008; 26: 148-151.

157. Jang JS, Kim KM, Choi JE, Cha SI, Kim CH, Lee WK et al. Identification of polymorphisms in the caspase-3 gene and their association with lung cancer risk. Mol Carcinog 2008; 47 383-390.

158. Devarajan E, Sahin AA, Chen JS, Krishnamurthy RR, Aggarwal N, Brun AM et al. Down-regulation of caspase 3 in breast cancer: a possible mechanism for chemoresistance. Oncogene 2002; 21: 8843-8851

159. O'Donovan N, Crown J, Stunell H, Hill AD, McDermott E, O'Higgins $N$ et al. Caspase 3 in breast cancer. Clin Cancer Res 2003; 9: 738-742.

160. Huang Q, Li F, Liu X, Li W, Shi W, Liu FF et al. Caspase 3-mediated stimulation of tumor cell repopulation during cancer radiotherapy. Nat Med 2011; 17: 860-866.

161. Soung YH, Lee JW, Kim HS, Park WS, Kim SY, Lee JH et al. Inactivating mutations of CASPASE-7 gene in human cancers. Oncogene 2003; 22: 8048-8052.

162. Lee WK, Kim JS, Kang HG, Cha SI, Kim DS, Hyun DS et al. Polymorphisms in the Caspase7 gene and the risk of lung cancer. Lung Cancer 2009; 65: 19-24.

163. Ponten F, Jirstrom K, Uhlen M. The Human Protein Atlas-a tool for pathology. J Pathol 2008; 216: 387-393.

164. Kim HS, Lee JW, Soung YH, Park WS, Kim SY, Lee JH et al. Inactivating mutations of caspase-8 gene in colorectal carcinomas. Gastroenterology 2003; 125: 708-715.

165. Soung YH, Lee JW, Kim SY, Sung YJ, Park WS, Nam SW et al. Caspase-8 gene is frequently inactivated by the frameshift somatic mutation 1225_1226delTG in hepatocellular carcinomas. Oncogene 2005; 24: 141-147.

166. Soung YH, Lee JW, Kim SY, Jang J, Park YG, Park WS et al. CASPASE-8 gene is inactivated by somatic mutations in gastric carcinomas. Cancer Res 2005; 65: 815-821.

167. MacPherson G, Healey CS, Teare MD, Balasubramanian SP, Reed MW, Pharoah PD et at. Association of a common variant of the CASP8 gene with reduced risk of breast cancer. J Natl Cancer Inst 2004; 96: 1866-1869.

168. Teitz T, Lahti JM, Kidd VJ. Aggressive childhood neuroblastomas do not express caspase-8: an important component of programmed cell death. J Mol Med (Berl) 2001; 79 : 428-436.

169. Grotzer MA, Eggert A, Zuzak TJ, Janss AJ, Marwaha S, Wiewrodt BR et al. Resistance to TRAIL-induced apoptosis in primitive neuroectodermal brain tumor cells correlates with a loss of caspase-8 expression. Oncogene 2000; 19: 4604-4610.

170. Ebinger M, Senf L, Wachowski O, Scheurlen W. Promoter methylation pattern of caspase8, P16INK4A, MGMT, TIMP-3, and E-cadherin in medulloblastoma. Pathol Oncol Res 2004 10: $17-21$

171. Martinez R, Setien F, Voelter C, Casado S, Quesada MP, Schackert G et al. CpG island promoter hypermethylation of the pro-apoptotic gene caspase- 8 is a common hallmark of relapsed glioblastoma multiforme. Carcinogenesis 2007; 28: 1264-1268.

172. Shivapurkar N, Toyooka S, Eby MT, Huang CX, Sathyanarayana UG, Cunningham HT et al. Differential inactivation of caspase-8 in lung cancers. Cancer Biol Ther 2002; 1: 65-69.

173. Teitz T, Wei T, Valentine MB, Vanin EF, Grenet J, Valentine VA et al. Caspase 8 is deleted or silenced preferentially in childhood neuroblastomas with amplification of MYCN. Nat Med 2000; 6: 529-535.

174. Stupack DG, Teitz T, Potter MD, Mikolon D, Houghton PJ, Kidd VJ et al. Potentiation of neuroblastoma metastasis by loss of caspase-8. Nature 2006; 439: 95-99.
175. Teitz T, Inoue M, Valentine MB, Zhu K, Rehg JE, Zhao W et al. Th-MYCN mice with caspase-8 deficiency develop advanced neuroblastoma with bone marrow metastasis. Cancer Res 2013; 73: 4086-4097.

176. Stupack DG. Caspase-8 as a therapeutic target in cancer. Cancer Lett2013; 332: 133-140.

177. Graf RP, Keller N, Barbero S, Stupack D. Caspase-8 as a regulator of tumor cell motility. Curr Mol Med 2014; 14: 246-254.

178. Shin MS, Kim HS, Kang CS, Park WS, Kim SY, Lee SN et al. Inactivating mutations of CASP10 gene in non-Hodgkin lymphomas. Blood 2002; 99: 4094-4099.

179. Kim MS, Oh JE, Min CK, Lee S, Chung NG, Yoo NJ et al. Mutational analysis of CASP10 gene in acute leukaemias and multiple myelomas. Pathology 2009; 41: 484-487.

180. Oh JE, Kim MS, Ahn CH, Kim SS, Han JY, Lee SH et al. Mutational analysis of CASP10 gene in colon, breast, lung and hepatocellular carcinomas. Pathology 2010; 42: 73-76.

181. Park WS, Lee JH, Shin MS, Park JY, Kim HS, Lee JH et al. Inactivating mutations of the caspase-10 gene in gastric cancer. Oncogene 2002; 21: 2919-2925.

182. Lamy L, Ngo VN, Emre NC, Shaffer AL 3rd, Yang Y, Tian E et al. Control of autophagic cell death by caspase-10 in multiple myeloma. Cancer Cell 2013; 23: 435-449.

183. Krajewska M, Kim H, Shin E, Kennedy S, Duffy MJ, Wong YF et al. Tumor-associated alterations in caspase-14 expression in epithelial malignancies. Clin Cancer Res 2005; 11: 5462-5471.

184. Wu M, Kodani I, Dickinson D, Huff F, Ogbureke KU, Qin H et al. Exogenous expression of caspase-14 induces tumor suppression in human salivary cancer cells by inhibiting tumor vascularization. Anticancer Res 2009; 29: 3811-3818.

185. Dinarello CA. Interleukin 1 and interleukin 18 as mediators of inflammation and the aging process. Am J Clin Nutr 2006; 83: 447S-455S.

186. Salminen A, Kaarniranta K, Kauppinen A. Inflammaging: disturbed interplay between autophagy and inflammasomes. Aging (Albany NY) 2012; 4: 166-175.

187. Gemma C, Fister M, Hudson C, Bickford PC. Improvement of memory for context by inhibition of caspase-1 in aged rats. Eur J Neurosci 2005; 22: 1751-1756.

188. LeBlanc AC. Caspase- 6 as a novel early target in the treatment of Alzheimer's disease. Eur J Neurosci 2013; 37: 2005-2018.

189. Fulle S, Sancilio S, Mancinelli R, Gatta V, Di Pietro R. Dual role of the caspase enzymes in satellite cells from aged and young subjects. Cell Death Dis 2013; 4: e955.

190. Someya S, Yu W, Hallows WC, Xu J, Vann JM, Leeuwenburgh C et al. Sirt3 mediates reduction of oxidative damage and prevention of age-related hearing loss under caloric restriction. Cell 2010; 143: 802-812.

191. Seidman MD, Khan MJ, Bai U, Shirwany N, Quirk WS. Biologic activity of mitochondrial metabolites on aging and age-related hearing loss. Am J Otol 2000; 21: 161-167.

192. Naidoo N, Ferber M, Master M, Zhu Y, Pack Al. Aging impairs the unfolded protein response to sleep deprivation and leads to proapoptotic signaling. J Neurosci 2008; 28: $6539-6548$.

193. Zhang Y, Padalecki SS, Chaudhuri AR, De Waal E, Goins BA, Grubbs B et al. Caspase-2 deficiency enhances aging-related traits in mice. Mech Ageing Dev 2007; 128: 213-221.

194. Shalini S, Dorstyn L, Wilson C, Puccini J, Ho L, Kumar S. Impaired antioxidant defence and accumulation of oxidative stress in caspase-2-deficient mice. Cell Death Differ 2012; 19: $1370-1380$.

195. Shalini S, Puccini J, Wilson CH, Finnie J, Dorstyn L, Kumar S. Caspase-2 protects against oxidative stress in vivo. Oncogene 2014; doi:10.1038/onc.2014.413.

196. Lopez-Cruzan M, Herman B. Loss of caspase-2 accelerates age-dependent alterations in mitochondrial production of reactive oxygen species. Biogerontology 2013; 14: 121-130.

197. Hyman BT, Yuan J. Apoptotic and non-apoptotic roles of caspases in neuronal physiology and pathophysiology. Nat Rev Neurosci 2012; 13: 395-406.

198. Kuo CT, Zhu S, Younger S, Jan LY, Jan YN. Identification of E2/E3 ubiquitinating enzymes and caspase activity regulating Drosophila sensory neuron dendrite pruning. Neuron 2006; 51: $283-290$

199. Erturk A, Wang Y, Sheng M. Local pruning of dendrites and spines by caspase-3dependent and proteasome-limited mechanisms. J Neurosci 2014; 34: 1672-1688.

200. Pozueta J, Lefort R, Ribe EM, Troy CM, Arancio O, Shelanski M. Caspase-2 is required for dendritic spine and behavioural alterations in J20 APP transgenic mice. Nat Commun 2013; 4. 1939 .

201. Ohsawa S, Hamada S, Kuida K, Yoshida H, Igaki T, Miura M. Maturation of the olfactory sensory neurons by Apaf-1/caspase-9-mediated caspase activity. Proc Natl Acad Sci USA 2010; 107: 13366-13371

202. Simon DJ, Weimer RM, McLaughlin T, Kallop D, Stanger K, Yang J et al. A caspase cascade regulating developmental axon degeneration. J Neurosci 2012; 32: 17540-17553.

203. Li Z, Jo J, Jia JM, Lo SC, Whitcomb DJ, Jiao S et al. Caspase-3 activation via mitochondria is required for long-term depression and AMPA receptor internalization. Cell 2010; 141 : 859-871. 